\title{
Kahramanmaraş Şehri Sel ve Taşkınlarının Coğrafi Analizi ve Öngörüler
}

\section{Flashflood and Flood Geographical Analysis and Foresight in Kahramanmaraş City}

\author{
Osman SARIGÜL ${ }^{1}$ (D), Hüseyin TUROĞLU² (1) \\ 'İstanbul Üniversitesi, Sosyal Bilimler Enstitüsü, Coğrafya Bölümü, İstanbul, Türkiye \\ ${ }^{2}$ İstanbul Üniversitesi, Edebiyat Fakültesi, Coğrafya Bölümü, İstanbul, Türkiye
}

ORCID: O.S. 0000-0002-4677-5157; H.T. 0000-0003-0173-6995

\section{öz}

Bu çalışmada Kahramanmaraş'ta yaşanan sel ve taşkın olaylarının coğrafi analizlerinin yapılması ve geleceğe yönelik öngörülerde bulunulması amaçlanmıştır. Araştırma kapsamında; yüzey analizleri, hidrolojik ve morfometrik analizler, arazi kullanımındaki zamana bağlı değişimin izlenmesi çalışmaları yapıımıştır. Bu çalışmalar; Mapınfo Professional 11.0 yazılımı ve 1/25000 ölçekli topografya haritalarından üretilen veritabanı kullanılarak yapılmıştır. Ayrıca günlük sıcaklık ve yağış rasatlarına dayalı Thornthwaite su bilançosu, yağış tipi ve yağışın mevsimsel değişimi, sıcaklık değişim özellikleri ve iklim analiz sonuçlarının lineer regresyon analizleri, regresyon denklemi ve $r^{2}$ değerlerine dayalı yağış ve sıcaklık öngörüleri bu araştırma kapsamında gerçekleştirilen diğer analizlerdir. Morfometrik analiz sonuçlarına göre akarsu havzalarının sel ve taşkın duyarlılıklarına bakıldığında; Akdere ve Erkenez Çayı havzalarında yüksek risk, Karaçay, Cancığın Dere, Kerhan Çayı havzalarında orta seviyede risk ve İğdeliöz, Ağcalıdere ve Boğazdere havzalarında ise riskin daha düşük olduğu görülmüştür. Şehrin kuzey yönde gelişmesiyle, kuzeydeki geçirimliliği yüksek ve eğimli sahaların geçirimlilik özellikleri büyük oranda zayıflatılmıştır. Bu durum; şehir merkezi istikametindeki yüzeysel akışın hızının ve miktarının artmasının, şehir merkezinde yaşanan sellerin afete dönüşmesinin, afetlerin sıklık ve şiddet özelliklerinin artmasının önemli nedeni olarak görünmektedir.

Anahtar kelimeler: Kahramanmaraş, Sel-Taşkın, Ahır Dağı

\section{ABSTRACT}

In this study, our aim was to employ a geographical analysis of flood and flash flood events in Kahramanmaraş and make predictions for the future. Within the scope of the research; surface analyses, hydrological and morphometric analyses, and monitoring of time-based change studies in land use were conducted. A database was created by using Maplnfo Professional 11.0 software and 1/25000 scale topography maps. Also, Thornthwaite water balance, rainfall types and its seasonal change, temperature change characteristics and linear regression analyses of climate analysis results, regression equation and rainfall and temperature predictions based on $r^{2}$ values were other analyses carried out within the scope of this research. According to the results of the morphometric analysis, looking at the flood and flash flood sensitivity of the stream basins, high risk in Akdere, Erkenez Stream Basins, moderate risk in Karaçay, Cancığın, Kerhan Stream Basins and lower risk in the Basins of Ĭğdeliöz, Ağcalıdere, Boğazdere were observed. An increase in impermeable grounds due to urbanization can encourage flood disasters by increasing the speed and amount of surface flow in the direction of the city center.

Keywords: Kahramanmaraş, Flashflood-Flood, Mount Ahır

Başvuru/Submitted: 20.03.2020 • Revizyon Talebi/Revision Requested: 26.04.2020 • Son Revizyon/Last Revision Received: 18.05 .2020 - Kabul/Accepted: 30.05.2020 • Online Yayın/Published Online: 19.06.2020 


\section{EXTENDED ABSTRACT}

Kahramanmaraş city center is located between Ahır Mountain in the north (an extension of the Eastern Taurus), and the Kahramanmaraş Plain in the south. In the north of the city, Mount Ahır rises to 2000 meters, while in the south the altitude on the plain area drops to 430 meters. The geomorphology on which the city is located consists of hillside plots in the north and plains located in the south. This area is drained by the Akdere, Keklikdere, Cephanelik Cancığın, İğdeliöz ,Ağcalı, Boğazdere, Karaçay, Erkenez and Kerhan Streams, which take their sources from the high parts of Ahır Mountain. These drainage canals, which have roughly semi-parallel patterns, pass from high slopes to the plain with a slope fracture and merge into the Aksu River. The geomorphological, hydrographic, climatological, soil, and vegetation characteristics and methods of benefiting from the land and interventions in natural systems via projects have all caused floods and flash floods, which have turned into disasters with an increase in frequency and effect in Kahramanmaraş city. In this study, our aim was to conduct a geographical analysis of flood and flash flood disasters occurring in Kahramanmaraş city center, and to have foresights for the future. Within the scope of the research, MapInfo Professional 11.0, one of the software of Geographic Information Systems (GIS), was used for mapping, altitude, slope, and hydrological and morphometric analyses. Also, studies have been carried out to monitor the time-dependent change in land use. Additionally, Thornthwaite water balance, based on the climate data that belongs to Kahramanmaraş Meteorology Station's daily temperature and rainfall observations provided by the General Directorate of Meteorology, seasonal change of rainfall type, temperature change characteristics and linear regression analyses of the climate analysis' results were performed. Rainfall and temperature predictions were employed using the regression equation and $\mathrm{r}^{2}$ values. The oldest official registration for a flood and flash flood that caused the loss of life in the city center dates back to 1972. On April 15, 1972, a total of $31.3 \mathrm{~mm}$ of rainfall fell, and after 50 minutes of severe rainfall, a mass of water that was 5-6 meters high and 50-60 meters in width, occurred in the Akdere basin and caused a major flood disaster in the region. After this event, 5 people died in the village of Dereli, which is located in the Akdere Valley, 27 houses were filled with deposits and 80 small animals were destroyed by floodwaters. In the following years, there have been many floods and flash floods in the city center, where property damage occurred. The most recent flood occurred in 2018. On June 13, 2018, rainfall, measured at $17.8 \mathrm{~mm}$ by the meteorological station in the city center, caused a serious flood. As a result of the flood, 3 people died and in some places, it damaged many homes, businesses and vehicles in the city center and in some places, the infrastructure of the city was also badly damaged. The maximum amount of rainfall per day was measured for the highest 100 units between 1959 and 2018 . When looking at the distribution of the daily maximum rainfall numbers by months, it was observed that rainfall decreased mostly in December, January, February and November, respectively. It was observed that the amount of maximum daily rainfall was in December with 98.2 mm, in February with $94.2 \mathrm{~mm}$, and in November with $72.0 \mathrm{~mm}$. It was noted that 30 of the top 100 maximum rainfall events which were measured in this period, decreased in the period after 2000. It can be said that this condition indicates a change in the city's rainfall regime. According to the results of morphometric analysis of the stream basins, the "highest risk" was seen in the Akdere and Erkenez Stream Basins when looking at flood and flashflood sensitivities. Both of the floods that caused the loss of life in the city center in 1972 and 2018 , occurred within the borders of the Akdere Basin. The Karaçay, Cancığın, and Kerhan Stream Basins have a "moderate risk", while in the Basins of İğdeliöz, Ağcalıdere and Boğazdere, a "low level of risk" was observed. With the development of the city in the north direction, the high and sloped areas of the city have been concreted. This causes an increase in the speed and quantity of water that are switched to the superficial flow towards the city center as a result of the rains. The role of urbanization in the north is significant in the occurrence of the flood in the city center. That is why the natural areas in the north of the city should be protected and the development of the city in a northerly direction should be prevented. 


\section{GíRiş}

Kahramanmaraş şehir merkezi, konum olarak Doğu Toroslar'ın bir uzantısı olan ve doğu-batı yönünde uzanış gösteren Ahır Dağı'nın güney yamacında kurulmuştur. Şehrin kuzey ve kuzeydoğusunda Ahır Dağı'nın yüksek ve eğimli yamaçları yer alırken hemen güneyde ise Maraş Ovası gibi düzlük alanlar bulunur. Şehir merkezi, güneyde ova tabanından başlayarak kuzeyde yer alan Ahır Dağı yamaçlarına doğru bir gelişim göstermiştir (Foto 1).

Bulunduğu konum itibariyle, şehir merkezi; kuzeydeki yüksek eğimli yamaçlardan gelen dereler nedeniyle sel ve taşkın olayları açısından riskli bir bölgede yer almaktadır. Şehir merkezinde bu derelerden gelen yağmur suları nedeniyle geçmişten günümüze birçok sel ve taşkın afeti yaşanmıştır. Meydana gelen bu afetler nedeni ile şehir merkezinde birçok can kaybı olmuş ve birçok ev, iş yeri ve araç zarar görmüştür (Foto 2).

Sel ve taşkınlar; bir bölgedeki, farklı kökenlere dayalı olarak ortaya çıkan ve mevcut drenaj sistemlerinin su taşıma kapasitelerine göre su fazlasının neden olduğu afetlerdir. $\mathrm{Bu}$ sebeple, hidrografik afetler olarak tanımlanırlar. Sel ve taşkınlar, oluşum şekilleri, meydana geliş nedenleri ve sonuçları itibariyle birbirinden farklı özellikler gösteren doğal afetlerdir (Turoğlu, 2010a). Yüzeysel akış ile yatak taşıma kapasitesi itibarıyla sıra dışı su kütlesinin bir araya gelmesi her ikisinin de ortak özelliği olmasına karşın, sel yüksek enerjili su hareketini, taşkın ise bu su kütlesinin geçici olarak göllenmesini tanımlar (Turoğlu, 2019).

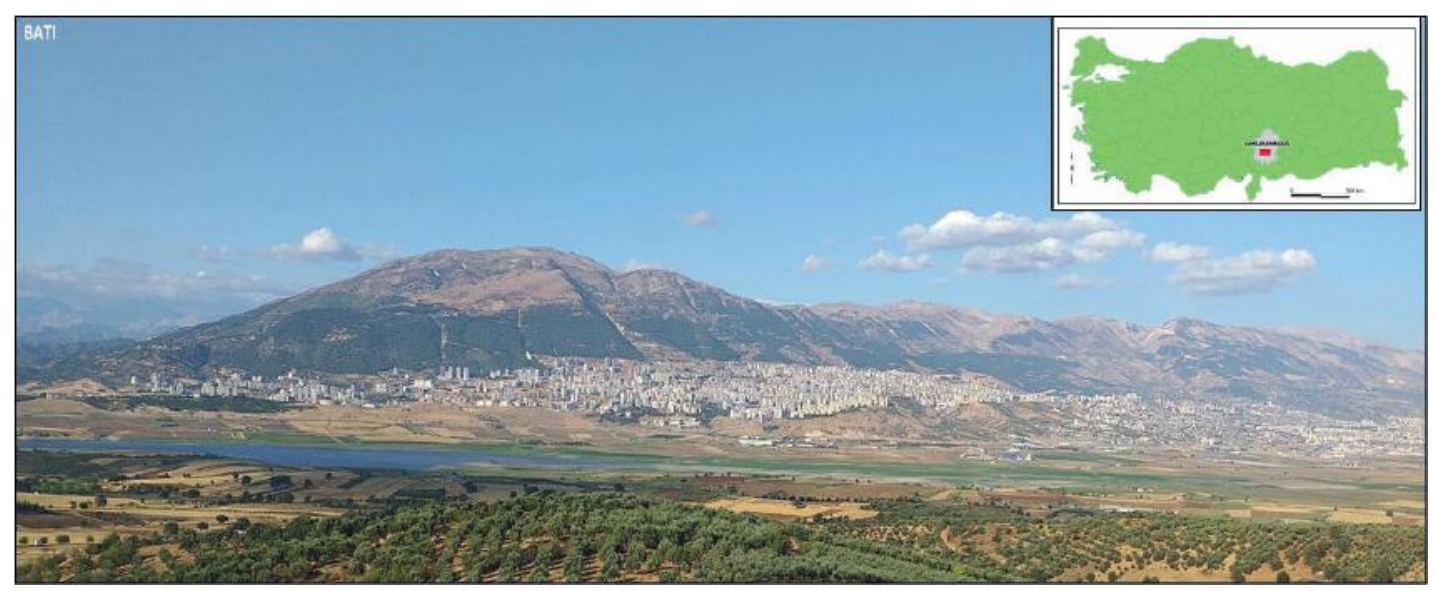

Foto 1: Kahramanmaraş Şehir Merkezinin Genel Görünümü (Güneybatıdan Bakış).

Photo 1: Overall View of Kahramanmaraş City Center (View From Southwest).



Foto 2: Şehir Merkezinde 2018 Yılında, 13 Haziran'da Yaşanan Sel Felaketinden Bir Görünüm. Photo 2: A Wiew From The Flood Disaster In The City Center In 2018 on June 13.

1 http://www.elbistaninsesi.com/guncel/kahramanmaras-ta-sel-hayati-felc-etti-h57277.html adresinden 24.04.2020 tarihinde alınmıştır. 
Bir bölgedeki yüzeysel akışı, dolayısıyla sel ve taşkınları etkileyen başlıca coğrafi faktörler; yağışın türü, süresi, şiddeti, miktarı, yağışın havza içindeki dağılışı ve evapotranspirasyonu etkileyen meteorolojik ve klimatik faktörler ile arazi kullanımı, arazi örtüsü, bitki örtüsü, toprak ve zemin özellikleri, drenaj alanı, drenaj havzasının şekli, yükselti, eğim özellikleri ve drenaj sistemleri ile bu drenaj sistemlerindeki yüzeysel akışı engelleyen baraj, göl ve gölet vb. yapıların varlığı gibi fiziki faktörlerdir. Akarsuların ortalamanın üstündeki akımları ile bunların mevsimsel salınımı, klimatik faktörlerin kontrolünde gerçekleşir. Fiziki faktörler ise bu süreçlerdeki pozitif salınımların bir afete dönüşmesinde şiddeti artırıcı ya da kontrol edici rol oynamaktadır (Turoğlu, 2010b; Turoğlu, 2019).

Sel ve taşkın olayları doğal süreçler kadar, beşeri faaliyetlerin de bir sonucu olarak ortaya çıkmaktadır. 2016 yılında dünyada ve ülkemizde yaşanan sel ve su baskını gibi doğal afetler, kırsal alanlardan ziyade daha çok şehir merkezlerinde yaşanmıştır. Plansız kentleşmeler nedeniyle bir doğal süreç olarak yağan mevsim normallerindeki bir yağmur bile şehir merkezlerinde büyük bir sel afetine dönüşebilmektedir (Ersoy, 2017).

Kahramanmaraş şehir merkezinde can kaybına neden olan sel ve taşkın olayına ait verilere bakıldığında, elde edilebilen en eski resmi kayıt 1972 yllına aittir. 15 Nisan 1972 tarihinde, toplam $31,3 \mathrm{~mm}$ yağış düşmüş ve 50 dakika süren sağanak yağış sonrasında, Akdere havzasında, yüksekliği 5-6 metre olan ve genişliği 50-60 metreyi bulan su kütlesi meydana gelmiş ve bunun sonucu bölgede büyük bir sel afeti yaşanmıştır. Bu olay sonrasında Akdere vadisi içerisinde yer alan Dereli köyünde 5 kişi hayatını kaybetmiş, 27 ev rüsubatla dolmuş ve 80 küçükbaş hayvan sel sularına kapılarak telef olmuştur. ${ }^{2}$

Şehir merkezinde can kaybının yaşandığ 2018 yllında meydana gelmiştir. 13 Haziran 2018'de şehir merkezindeki meteoroloji istasyon verilerine o tarihte $17,8 \mathrm{~mm}$ yağı̧̧ düşmüş ve şehir merkezinde ciddi bir sel afeti meydana gelmiş̧ir. Yaşanan sel afeti sonucu, 3 kişi hayatını kaybetmiş ve şehir merkezinde birçok ev, iş yeri ve araç zarar görmüş bazı yerlerde şehrin alt yapısı büyük zarar görmüştür.

Kahramanmaraş şehir merkezinde sel ve taşkın konusunda ilk çalışma Sunkar ve Denizdurduran (2015) tarafından yapılmıştır. Bu çalışmada 14 Ekim 2010 ve 12 Mayıs 2015 yıllarında yaşanan sel ve taşkın olayları incelenmiştir. Belirtilen tarihlerde meydana gelen olaylarda herhangi bir can kayb1 yaşanmazken şehir merkezinde önemli maddi hasarlar meydana gelmiştir. Sunkar ve Denizdurduran'a (2015) göre şehir merkezinde sel ve taşkın afetlerinin son 15-20 yıllık dönemde artış gösterdiği, bu durumun yaşanmasında fiziki faktörlerin etkili olduğu ancak ciddi maddi hasarların meydana gelmesinde şehir merkezindeki derelerin kapalı kanallara alınması gibi asıl beşeri faktörler etkili olmuştur. Ancak çalışmada fiziki faktörler detaylı olarak ele alınmamıştır. Bu çalışmada önceki çalışmalardan farklı olarak, hem bu konudaki boşluğun doldurulması amaçlanmış hem de sel ve taşkınlar konusunda şehir merkezini etkileyen coğrafi faktörler bir bütün halinde ele alınıp incelenerek, aralarındaki ilişkiler ortaya konulmuştur.

\section{AMAÇ VE YÖNTEM}

Kahramanmaraş şehir merkezini etkileyen sel ve taşkın olaylarının coğrafi analizi kapsamında fiziki ve beşeri faktörlerden ele alınan unsurlar ve kullanılan yöntemlerin kapsam şeması Şekil 1'de verilmiştir.

Kahramanmaraş şehir merkezi ve yakın çevresine ait jeolojik özelliklerden litolojik birimlerin dağıllışı ve bu litolojik birimlerin geçirgenlik özellikleri, Devlet Su İşleri (DSI) 20. Bölge Müdürlüğü tarafından Ceyhan Havzası Master Plan Çalışmaları kapsamında hazırlanan Ceyhan Havzası Hidrojeoloji Raporu (2015) verilerine göre oluşturulmuştur. Diğer yandan yükselti, eğim ve hidrografya haritaları Harita Genel Komutanlığının 1/25 000 ölçekli topografya haritaları üzerinden oluşturulmuştur. Şehir merkezinin klimatik analizlerinde ise il merkezine ait 1959-2018 y1lları arası Meteoroloji Genel Müdürlüğünün günlük ortalama ve maksimum sıcaklık rasat verileri ile aylık ve günlük toplam yağış rasat verileri kullanılmıştır.1959-2018 arası dönem, sıcaklık ve yağış özellikleri açısından 30'ar yıllık iki farklı periyotta incelenmiş ve bu dönem ortalamaları karşılaştırılarak liner regresyon analizleri ortaya konmuştur. Yağışlar, Ekim-Mart (nemli dönem) ve Nisan-Eylül (kurak dönem) dönemlerine göre sınıflandırılarak yağışların dönemsel değişim trendleri ortaya konmuştur. Diğer yandan Türkiye İstatistik Kurumu (TÜIK) verilerinden yararlanılarak şehir merkezinin nüfus gelişimi belirlenmiştir. Şehrin arazi örtüsü ve arazi kullanımındaki değişimler incelenmiştir. Kahramanmaraş Orman İşletme Şeflikleri tarafından hazırlanan Amenajman haritalarına göre ise orman örtüsü kapalılık haritaları oluşturulmuştur. Haritaların oluşturulmasında CBS yazılımlarından MapInfo Professional 11.0 ve Global Mapper 15.0 kullanılmıştır. Yapılan haritalar, arazi çalışmaları ile sahada teyit edilmiştir.

2 https://www.ogm.gov.tr/ekutuphane/OGMProjeler/Kahramanmara\%C5\%9F\%20Ye\%C5\%9Filku\%C5\%9Fak\%20Projesi.pdfadresinden 11.08.2019 tarihinde alınmıstır. 


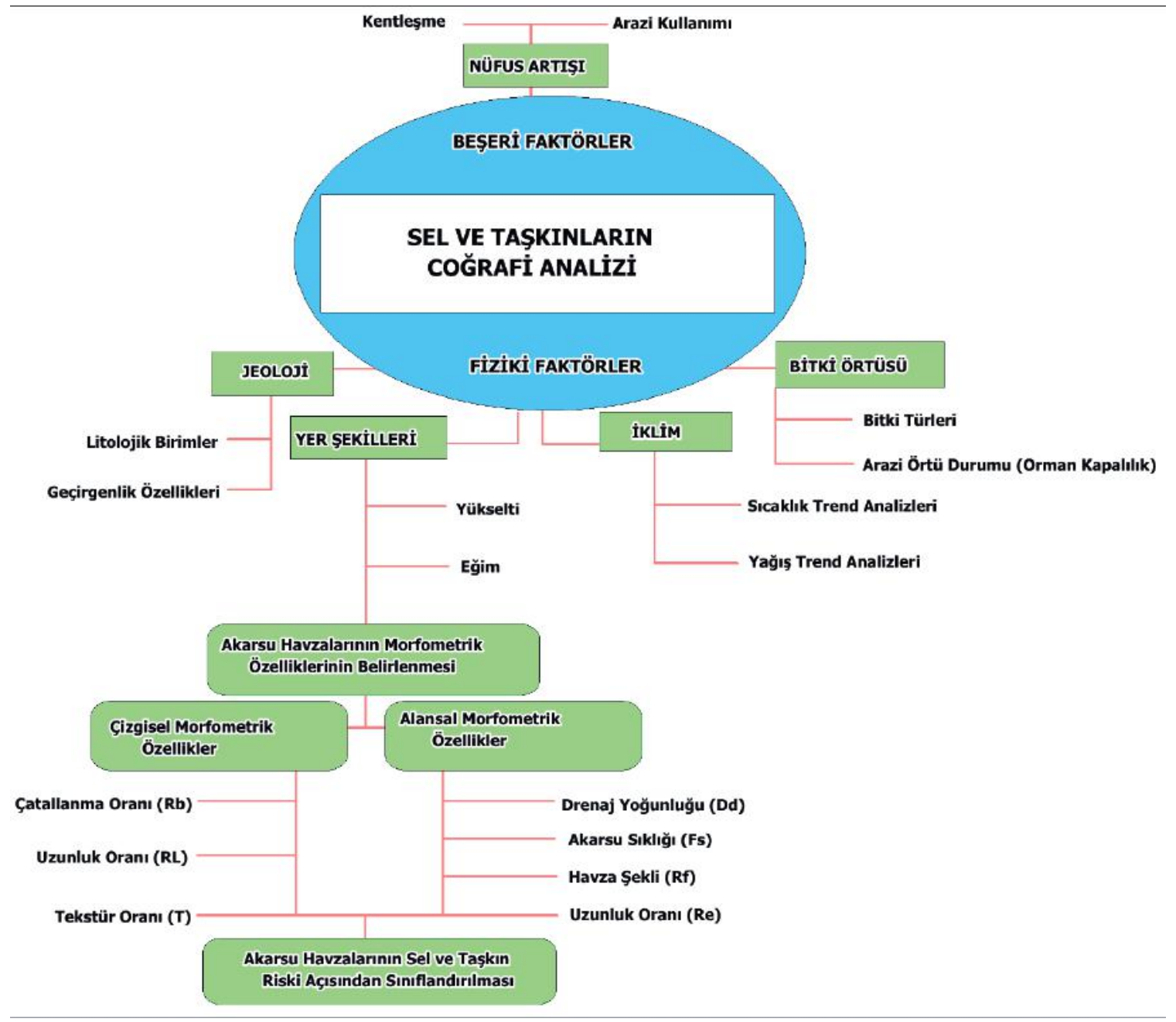

Şekil 1: Çalışmada kullanılan veri ve yöntemlerin kapsam şeması.

Figure 1: Scope chart of data and methods used in the study.

Bununla birlikte şehir merkezi için sel ve taşkın riski oluşturan akarsuların Strahler yöntemine göre dizin sayıları hesaplanmış ve söz konusu akarsuların havza alanları belirlenerek, morfometrik analizleri yapılmıştır. $\mathrm{Bu}$ analizlerin hesaplanmasında çizgisel morfometrik özelliklerden Çatallanma oran1 $(R b)$, (Strahler 1964; Schumm, 1956); Uzunluk oran1 $(R L)$, (Horton, 1945; Strahler, 1964) ve Tekstür oranları (T), (Horton, 1945)'e göre hesaplanmıştır. Alansal morfometrik özelliklerden ise Drenaj yoğunluğu (Dd), (Horton, 1945); Akarsu sıklığı $(F s)$, (Horton, 1945); Havza şekli (Rf), (Horton, 1945) ve Uzunluk oranları (Re), (Schumm, 1956)'a göre hesaplanmıştır. Çizgisel ve alansal morfometrik parametre analizleri yapılmış ve bu morfometrik analizler, şehir merkezindeki sel ve taşkın olaylarına akarsuların havza özelliklerinin de etkisini ortaya koymak açısından değerlendirilmiştir. Çalışmanın kapsamı gereği çalışmada morfometrik analizlerin hesaplanması konularının detaylarına değinilmemiştir. Sonuç olarak Kahramanmaraş şehir merkezini sel ve taşkın afeti açısından etkileyen akarsu havzalarının risk sınıflandırılması yapılmış ve bu konuda bazı öngörüler ortaya konulmuştur.

\section{BULGULAR}

\subsection{Jeolojik Özellikler}

Bir bölgedeki araziyi oluşturan litolojik birimlerin geçirimlilik özellikleri sel ve taşkın olayları üzerindeki etkisi önemlidir. Özellikle zeminin kaya ya da taneli yapıda olması, aşınmaya karşı gösterdikleri direnç, gözeneklilik ve geçirgenlik gibi özellikler o bölgedeki erozyon miktarı ve zeminin infiltrasyon kapasitesini belirler. Yağış sularının ne kadarının sızmaya uğrayacağı ve ne kadarının yüzeysel akışa geçeceği, arazinin jeolojik özellikleri ile yakın ilişkilidir. Şehir merkezi ve yakın çevresinde yayılış gösteren litolojik birimlerin dağılışı Harita 1'de verilmiştir. 


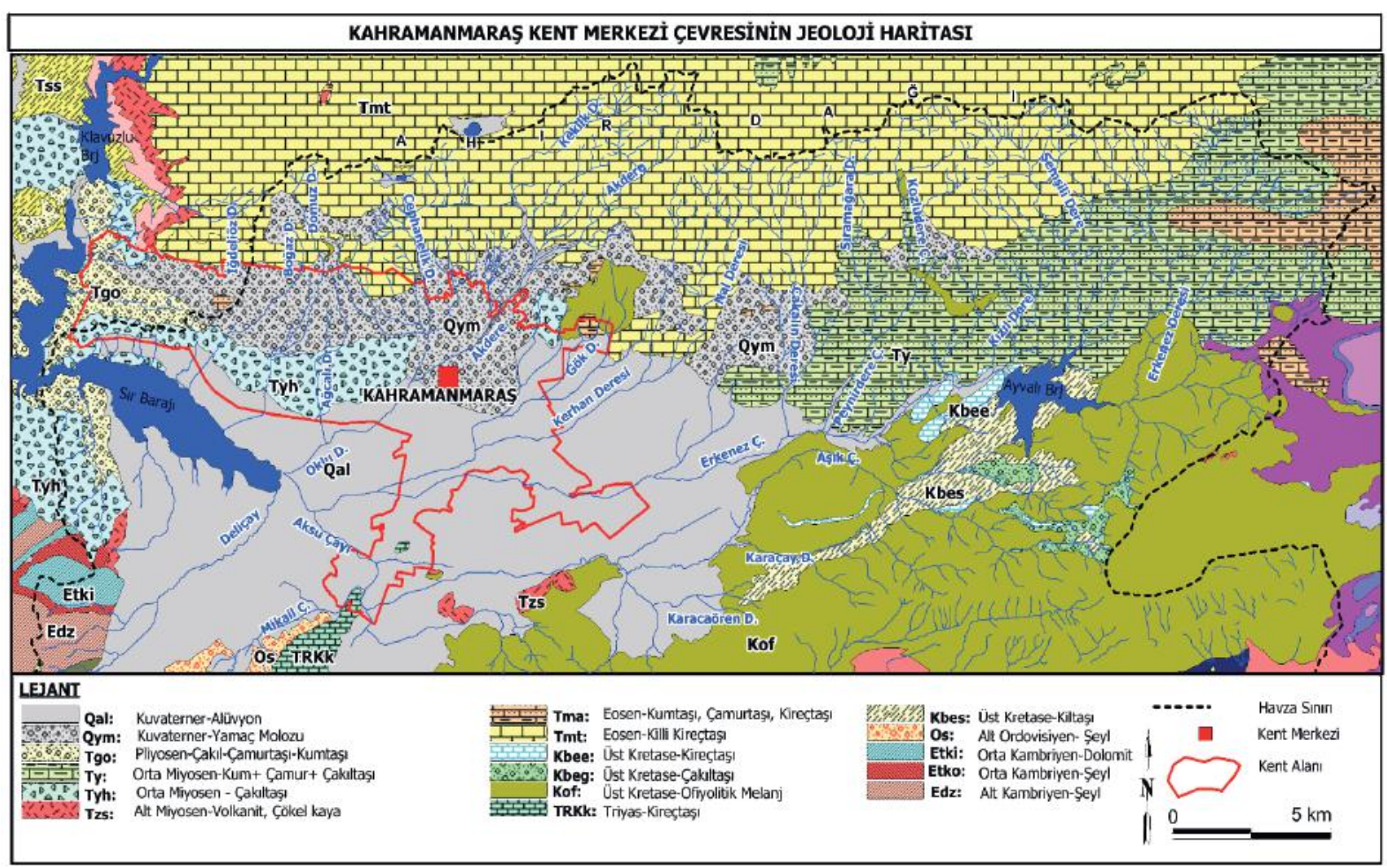

Harita 1: Şehir Merkezi ve Yakın Çevresinin Jeolojik Birimleri. ${ }^{3}$

Map 1: Geological Units of the City Center and Its Immediate Surroundings.

Harita 1'de verilen şehir merkezi ve yakın çevresinde bulunan arazilere bakıldığında şehrin güneyinde Maraş Ovası üzerindeki kalan sahalarda Kuvaterner alüvyonları (Qal) yer almaktadır. Kuzeye doğru gidildikçe Ahır Dağı yamaçlarında Orta Miyosen çakıl taşları (Tyh) ve Kuvaterner dönemine ait birikinti konileri, yamaç molozları (Qym) yer almaktadır. Daha yüksek kesimlere çıkıldığında ise Akdere ve Keklik Dere'nin kaynağını aldığı Ahır Dağı zirvelerinde tamamen Eosen killi kireçtaşları (Tmt) birimlerine geçilir. Şehir merkezine ulaşan birçok derenin kaynağını aldığı yerlerde hâkim formasyon, Eosen killi kireç taşlarından oluşmaktadır (Foto 3). Kuzeydoğuya doğru Peynirdere Çayı havzasında Orta Miyosen, kumtaşı, çamur taşı, çakıl taşı (Ty) birimleri yer alır. Güneydoğu kesimlere doğru gidildiğinde ise Mesozoik, Ofiyolitik kayaçlarından oluşan melanj (Kof) birimleri bulunur.

Bir bölgede sızma şiddetinin, yağış şiddetinden fazla olduğu durumlarda yüzeysel akış olmaz ve tüm yağış sızmaya uğrar. Sızma şiddetinin, yağış şiddetinden küçük olduğu durumlarda ise hem sızma hem de yüzeysel yağış meydana gelir. Eğer ki sızma şiddeti ile yağış şiddeti birbirine eşit olduğu durumlarda ise yüzeysel akış gerçekleşmez (Şen, 2003). Sızma, yüzeysel akıştaki su miktarında kayıplara neden olan bir etki yaratır (Bayazıt, 1995). Bu nedenle, bir yerdeki zeminin geçirgenlik özellikleri, o bölgedeki sel ve taşkın potansiyelinin belirlenmesinde önemlidir.

Şehir merkezi ve yakın çevresinin litolojik birimleri incelendiğinde, litolojik birimler içerisinde en yüksek geçirgenliğe sahip olan birim \% 35 ile Kuvaterner, yamaç molozlarının (Qym) olduğu görülmektedir. Geçirgenliğin yüksek olduğu bu birimler, şehir merkezinin kuzeye genişlemesi ile neredeyse tamamen betonlaştırılmış durumdadır. Geçirgenliğin yüksek olduğu diğer birimler ise \% 30 civarında olan Kuvaterner alüvyonları (Qal) olup genellikle şehrin güneyinde, ovalık alanlarda yer almaktadır. Şehir merkezine gelen birçok derenin beslenme alanını da oluşturan Ahır Dağı'nın yüksek kesimlerindeki Eosen killi kireç taşı (Tmt) birimlerinde ve şehir merkezinin güneydoğu kesimlerinde yer alan, Üst Kretase dönemine ait Ofiyolitik kayaçlarda (Kof) ise geçirgenlik \% 15 oranındadır. Kahramanmaraş şehrinin kuzeydoğusunda yer alan Orta Miyosen, kum taşı, çamur taşı ve çakıl taşı (Ty) arazileri; \% 5 oranıyla, geçirgenliğin en düşük olduğu birimlerdir (DSİ, 2015). 


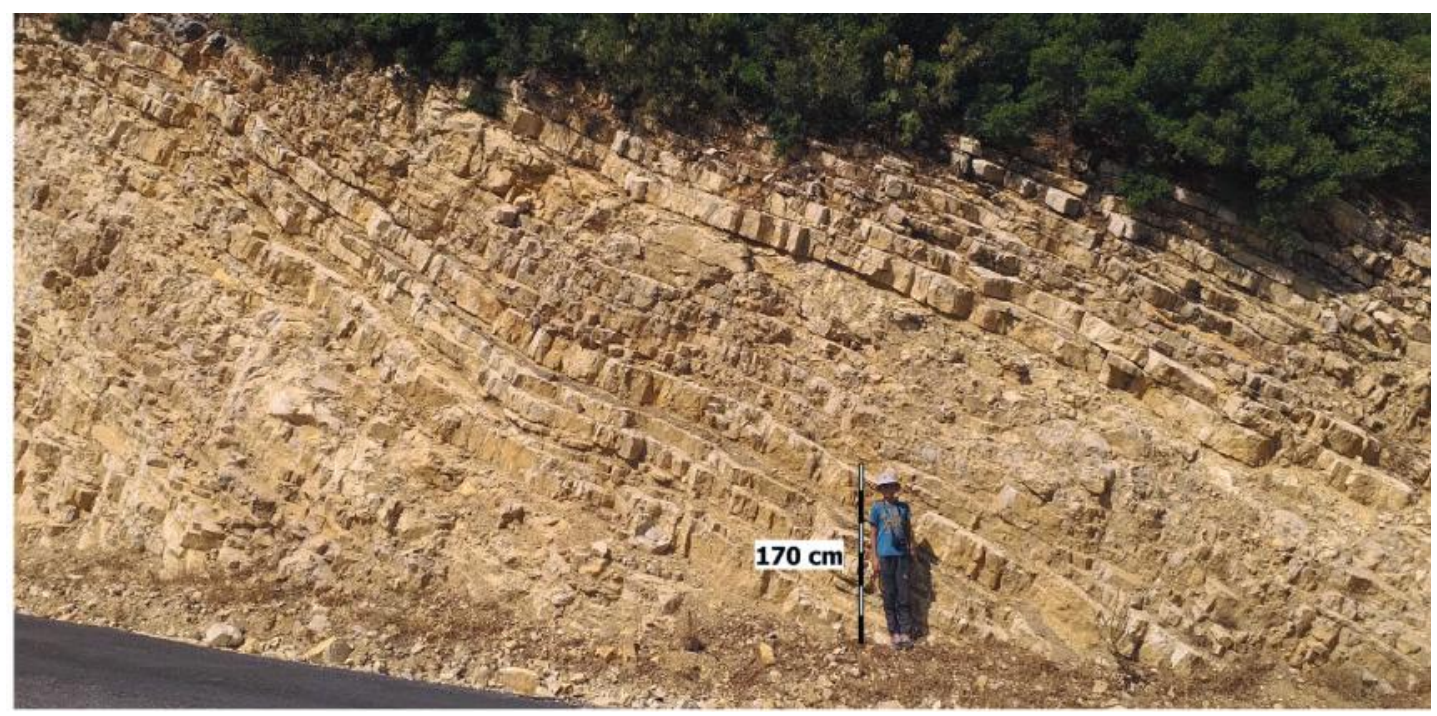

Foto 3: Ahır Dağı Yamaçlarında Yer Alan Eosen Killi Kireç Taşı Formasyonlarından Bir Görünüm.

Photo 3: A View from the Eocene Clayey Limestone Formations Located on the Slopes of Mount Ahır.

Kahramanmaraş şehir merkezi ve yakın çevresindeki litolojik birimlerin geçirgenlik durumları Harita 2'de verilmiştir. ${ }^{4}$

Şehir merkezinin genel olarak kuzeyinde geçirgenliği düşük litolojik birimler bulunurken güneyinde ise geçirgenliği yüksek birimler yer alır. Özellikle şehrin kuzeyinde yer alan yüksek ve eğimli alanlardaki geçirgenliğin az olması ve geçirgenliğin yüksek olduğu arazileri ise kentsel alanların kaplaması, yağış sularının derelerle şehir merkezine ulaşma süresini kısaltırken gelen su miktarını da artırdı̆̆ını söylemek mümkündür (Harita 2).

\subsection{Jeomorfolojik Özellikler}

Şehir merkezinin hemen kuzeyinde, Doğu Toroslar'ın bir uzantısı olan ve doğu batı doğrultusunda uzanış gösteren Ahır Dağı yer almaktadır. Güneyde ise Kahramanmaraş Ovası yer alır. Şehir merkezinin kuzeyi ile güneyi arasında önemli yükselti

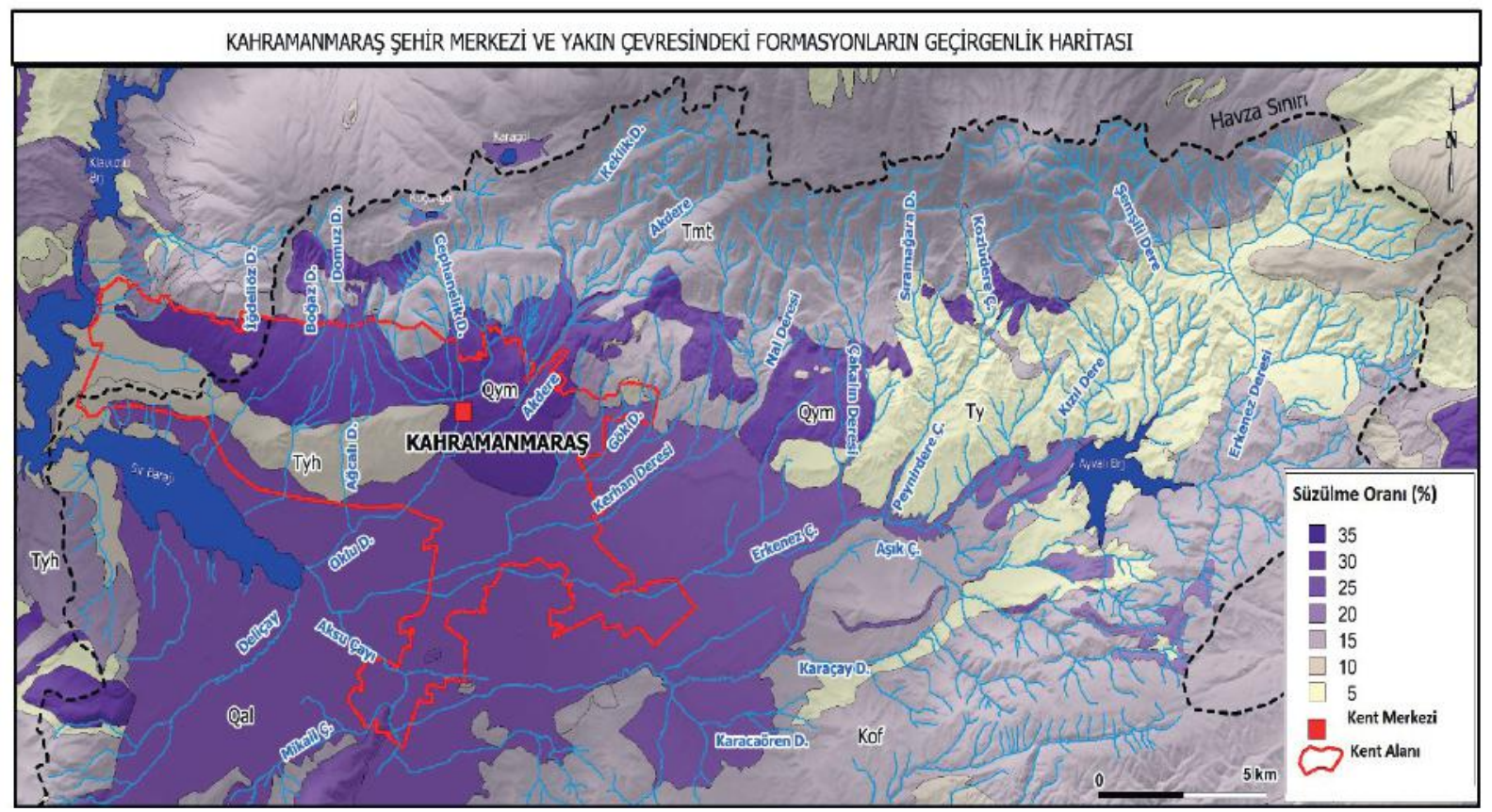

Harita 2: Şehir Merkezi ve Yakın Çevresinin Litolojik Geçirgenlik Durumları. ${ }^{4}$

Map 2: Lithological Permeability States of the City Center and Its Immediate Surroundings.

4 DSİ 2015, Ceyhan Havzası Hidrojeoloji Raporu, 6 Nolu Alt Havza verilerine göre düzenlenmiştir (Ek-6). 


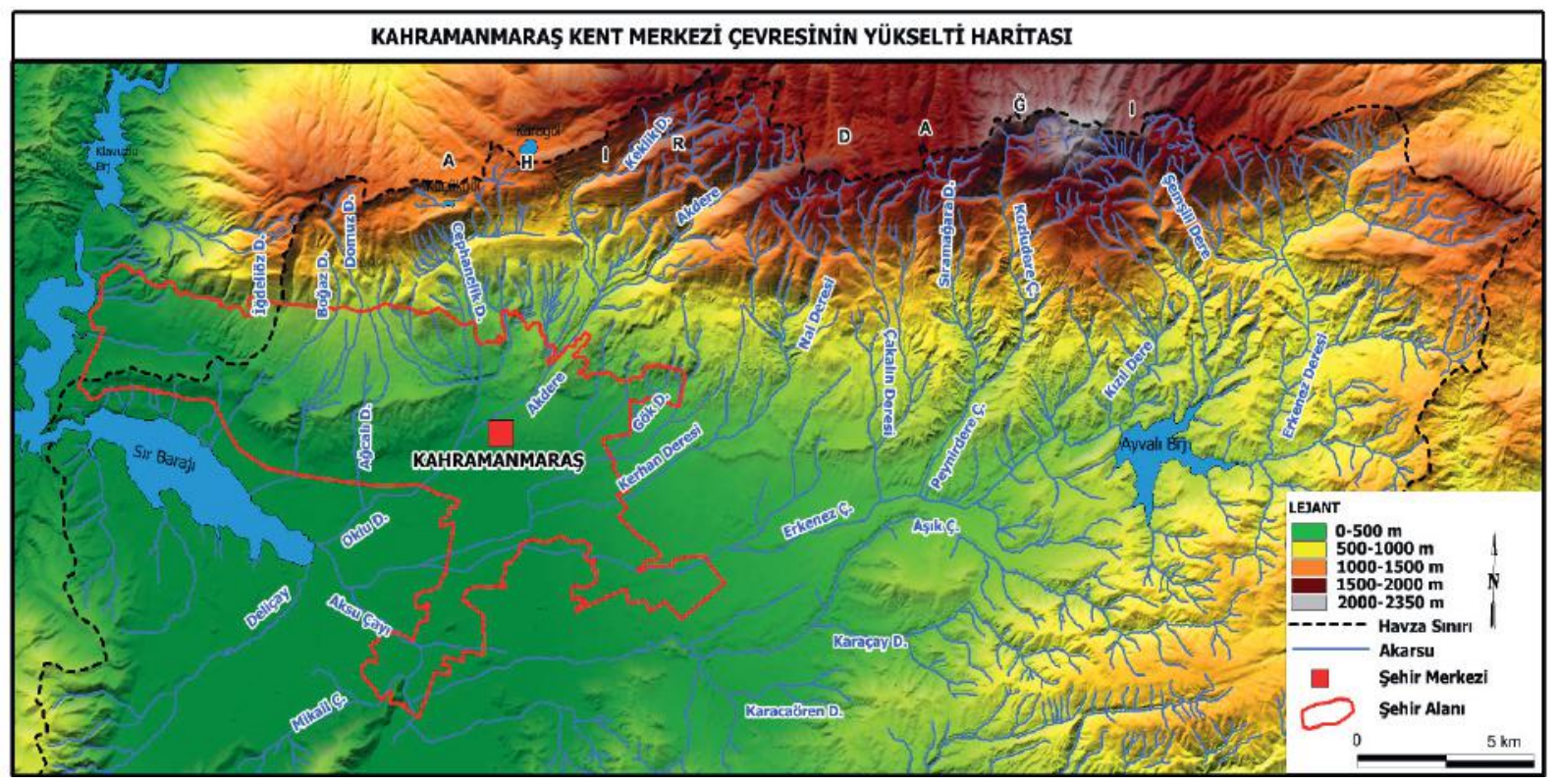

Harita 3: Kahramanmaraş Şehir Merkezi ve Yakın Çevresinin Yükselti Özellikleri. Map 3: Altitude Properties of Kahramanmaraş City Center and Its Immediate Surroundings.

farkları bulunmaktadır. Şehir merkezinden kuzey ve kuzeydoğu doğru gidildikçe yükselti ve eğim artar. Kuzeyde Ahır Dağı'nın yüksek ve eğimli yamaçlarından kaynağını alan ve birbirine paralel uzanan birçok dere, güneyde yer alan şehir merkezine doğru akış gösterir. Dağlık alanlarda yükseltisi 2345 metreye ulaşan seviyelerden kaynağını alan bu dereler, güneyde 420-500 metre arasında yer alan Maraş Ovası'na doğru bir akış gösterir. Ova tabanında birleşen bu dereler, havzanın ana akarsuyu olan Aksu Çayı tarafından Ceyhan Nehri üzerinde kurulmuş olan Sır Barajı'na drene edilir (Harita 3).

Genel olarak bir dağ yamacı boyunca yükselti ile birlikte yağış da artış gösterir (Atalay, 2013). Bundan dolayı güneydeki ovalık alanlara göre şehrin kuzeyindeki Ahır Dağı yamaçları daha çok yağış alır. Şehir merkezine ait meteoroloji istasyonu, ova kenarında yaklaşık 565 metre civarında yükseltide yer almaktadır. Bu nedenle istasyonun yağış verilerinin yükseltisi 2345 metreye kadar ulaşan Ahır Dağı yamaçlarına düşen yağışları tam olarak temsil ettiğini söylemek mümkün değildir. 13 Haziran 2018 yılında meydana gelen sel afetinde o gün için meteoroloji verileri toplam 17,8 mm yağış göstermiştir. Fakat şehir merkezinde yaşanan sel afetinin tahribat boyutlarına bakıldığında bunun çok daha yüksek bir yağış miktarının ortaya koyabileceği bir doğal afet olduğuna işaret etmektedir. Ayrıca yükseltinin oldukça fazla olduğu kesimlerde kış mevsimi yağışlarının çoğu kar şeklinde düşmekte ve bahar dönemine

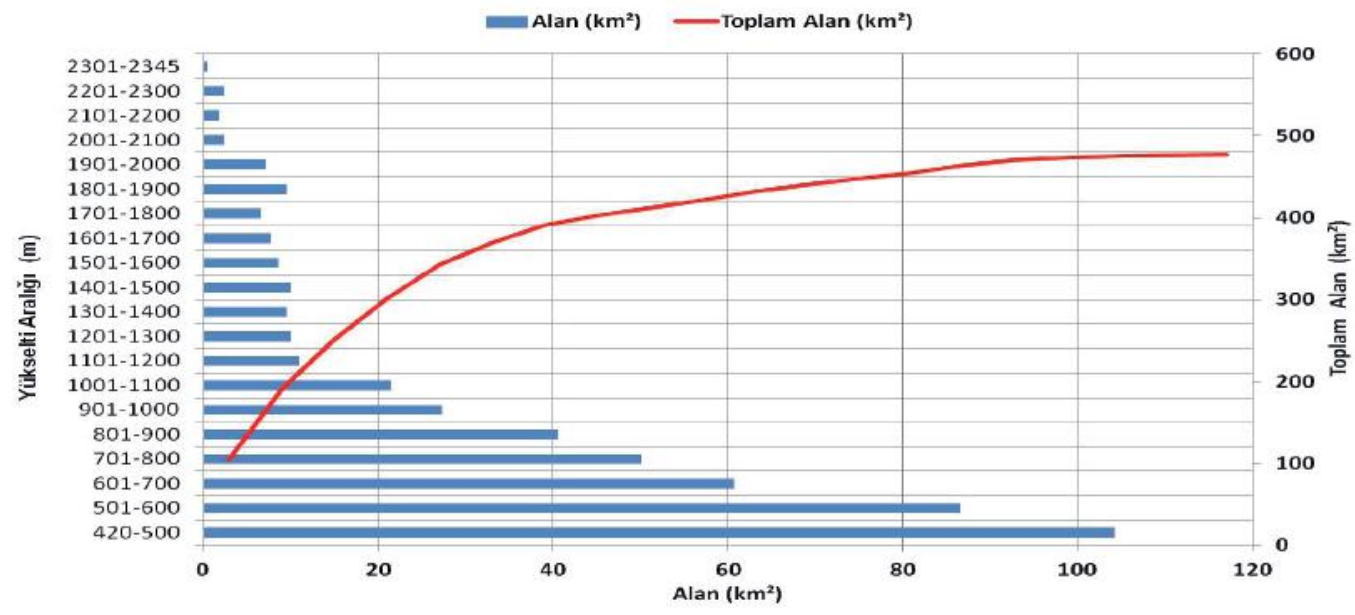

Şekil 2: Kahramanmaraş ve Yakın Çevresinin Yükselti-Alan Grafiği.

Figure 2: Elevation-Area Graphic of Kahramanmaraş and Its Vicinity. 


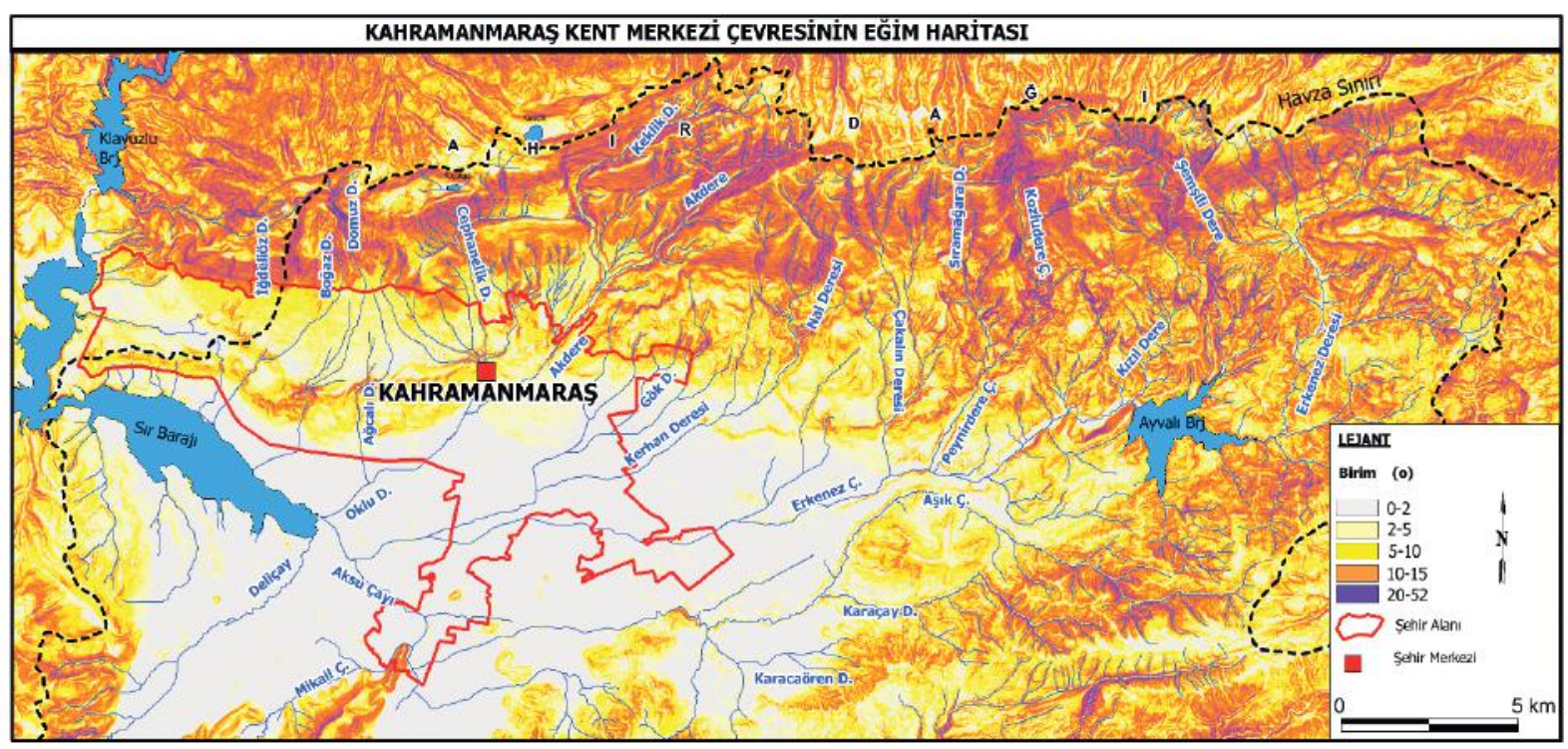

Harita 4: Şehir Merkezi ve Çevresinin Eğim Özellikleri.

Map 4: Slope Features of the City Center and Its Immediate Surroundings.

kadar kar örtüsü yerde kalmaktadır. Bahar döneminde havaların 1sınmasıyla birlikte buradaki karların erimeleri, yamaçlardan inen derelerdeki akımı artırıcı bir rol oynamaktadır.

Şehrin günümüz yerleşim üst sınırı 800-850 metre arasında bulunur. Şehir çevresindeki alanların \% 37'sinin şehrin yerleşim üst sınırından daha yüksek sahalar olduğu görülmektedir. Şehir merkezinin bugünkü üst sınırı ile bölgenin en yüksek noktası arasında yaklaşık 1500 metre yükselti farkının olduğu görülmektedir (Şekil 2). Şehir merkezindeki sel ve taşkın olayları ile ilgili derelerin şehir merkezine ulaşmadan önce önlemlerin alınacağı sahaları, $850 \mathrm{~m}$ ile 2345 metre arasında kalan bölgeler oluşturmaktadır. $\mathrm{Bu}$ yüzden şehre doğu akış gösteren derelere etkileri bakımından bu sahalardaki işleyen doğal ve beşeri süreçlerin denetimi önem arz etmektedir.
Şehir merkezi ve yakın çevresindeki eğim değerlerine bakıldığında ise güneyden, kuzey ve kuzeydoğuya doğru gidildikçe eğim değerleri artar. Güneyde yer alan Maraş Ovası tabanında eğim değerleri $0^{\circ}-2^{\circ}$ derece arasında değişirken kuzeydeki Ahır Dağı yamaçlarına doğru çıkıldıkça ciddi bir artış göstererek yer yer $50^{\circ}$ 'nin üzerine çıkmaktadır (Harita 4).

Şehir merkezini etkileyen akarsuların çoğu, kaynağını kuzeydeki yüksek eğimli arazilerden alırlar. Akdere, Keklik Dere, Cephanelik deresinin kaynağını aldığı sahalarda eğim değerleri $50^{\circ}$ civarına ulaşmaktadır. Yüksek eğimli bu yerlerde litolojik olarak geçirgenliği düşük olan Eosen killi kireçtaşları yaygındır. Bu yamaçlar aynı zamanda şiddetli erozyon sahalarıdır (Foto 3, a). Özellikle Akdere ve Keklik dere havzalarında vadi yamaçlarındaki şiddetli eğimin varlığı o bölgelerde yapılacak

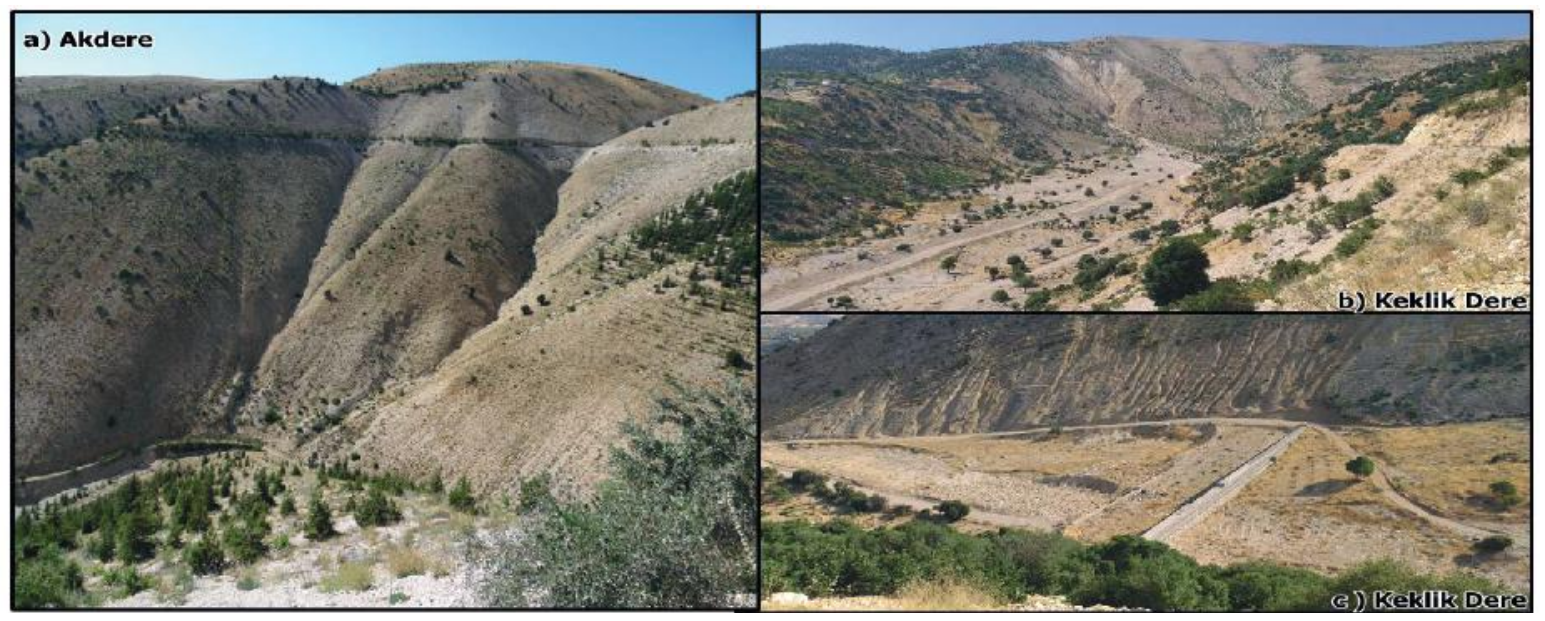

Foto 4: Akdere ve Keklik Dere Vadilerinden Bir Görünüm.

Photo 4: A View from Akdere and Keklik Dere Valleys. 
olan ağaçlandırma çalışmalarına engel olacak düzeydedir. Bu sahalarda yağış sonrası yüzeysel akımlarla yüksek ve eğimli yamaçlardan vadi tabanlarına ciddi miktarda rüsubat taşınımı gerçekleşmektedir (Foto 4, b). Bunu engellemek için DSİ tarafından bazı dere yataklarında tersip bentleri inşa edilmiştir (Foto 4, c).

Ahır Dağı yamaçlarından kaynağını alan birçok dere, şehir merkezine ulaştıklarında, dere yatakları daraltılarak kapalı kanallara alınmıştır (Foto 5 b). Kapalı kanallara alınmış olan bu derelerin üzeri ve bugün şehrin önemli caddelerini oluşturmaktadır. $\mathrm{Bu}$ caddelerin ismi günümüzde hala Kanlıdere, Şekerdere, Çayıniçi gibi eski derelerin isimleri ile anılmaya devam etmektedir.

Şehrin alansal olarak genişlemesi ile birlikte kapalı kanallara ve menfez geçişlerine alınan dere sayıları da giderek artmıştır. Ancak kapalı kanal ve menfezler, düzensiz rejimli bu derelerin akım miktarlarındaki değişikliklerde, özellikle derelerin sıra dışı akıma ulaştıkları dönemlerde gelen suların drene edilmesinde yetersiz kalmaktadırlar. Bu projelendirme hataları; sel, taşkın, çökme, kayma gibi problemleri tetiklemekte ya da şiddetlerinin artmasına neden olmaktadır. Bu nedenden dolayı en son 2018 yılında yaşanan sel afetinde kapalı kanalların geçtiği güzergâhtaki bazı bölgelerde göçmeler meydana geldiği görülmüştür.

\subsection{Morfometrik Özellikler}

Sel ve taşkın olaylarında bu olaylara neden olan akarsuların havza özelliklerinin etkisi oldukça büyüktür. $\mathrm{Bu}$ yüzden akarsulara ait havza özelliklerinin de ortaya konulması önemli bir husustur. Akarsu havzalarına ait özelliklerin, sayısal ifadelerle açılanabilir hale getirilmesi, akarsuyun havzası ile ilgili rasyonel açıklamaların yapılmasına imkân tanır (Turoğlu, 1997). Sel ve taşkınlar, her ne kadar yatak su taşıma kapasitesinin üstündeki su fazlalığından kaynaklanan doğal afetler olarak görülse de bu olaylar aynı zamanda doğrudan ve dolaylı olarak akarsu havzasının jeomorfolojisi ile de ilişkilidir. Yüzeysel akışa geçen suların miktarını belirlemesi açısından bitki örtüsü özellikleri, sızma özellikleri açısından zemin-toprak özellikleri ve bu sızma ve bitki örtüsünden arta kalan suların akışı ile jeomorfolojik özellikler arasındaki ilişki, bu afetlerin meydana geliş nedenlerinin açıklanabilmesi açısından oldukça önemlidir (Özdemir, 2011).

Şehir merkezini etkileyen akarsuların havza morfometrik özelliklerinin ortaya konulmasında öncelikle akarsuların Strahler yöntemine göre dizin sayıları hesaplanmıştır (Harita 5). Bu hesaplamada şehir merkezini etkileyen İğdeliöz deresi, Boğazdere, Cancığın Dere, Ağcalıdere, Akdere, Kerhan Çayı, Karaçay ve Erkenez Çayı ve bu akarsuların havzaları dikkate alınmıştır. Her bir havza için yapılan morfometrik analizlerden çizgisel ve alansal parametrelerin analizleri yapılarak analiz sonuçları daha sonra duyarlılık analizi açısından değerlendirilmiştir. Akarsu dizinleri; Harita Genel Komutanlığının 1/25000 ölçekli topografya haritalarına göre belirlenmiştir. Şehir merkezinde derelerin kaybolduğu alanlarda Global Mapper 15.0 yazılımı kullanılarak drenaj ağı tamamlanmıştır.

Şehir merkezini etkileyen akarsuların dizin sayılarına bakıldığında, 1 dizin ile en az dizin sayısı İğdeliöz Deresinde olduğu görülmektedir. Bunu 2 dizin ile Boğazdere, Ağcalıdere ve 3 dizinle Cancığın Dere takip etmektedir. Kerhan Çayı ile Karaçay 4 dizine sahipken Akdere ve Erkenez Çayı ise 5 dizine sahiptir. Akdere ve Erkenez Çayı havzalarının 5 dizin ile şehir merkezine en fazla su taşıyan havzalar olduğu görülmektedir Akarsulardaki 1. ve 2. dizinler genellikle Ahır Dağı'nın güney yamaçlarındaki yükselti ve eğimin fazla olduğu alanlarda yaygın olarak görülür. Yüksek kesimlerden şehir merkezine ve ovalık alana doğru inildikçe akarsulara katılan kol sayısının artması ile

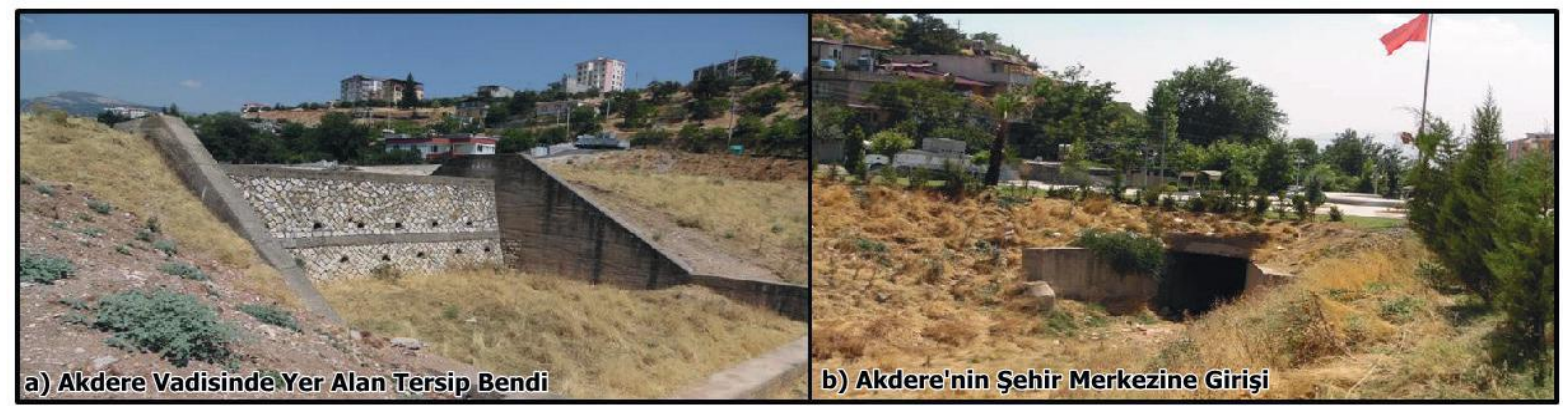

Foto 5: Akdere'nin Şehir Merkezine Girişte Kapalı Kanala Girişi.

Photo 5: Akdere's Entrance to the Enclosed Channel at the Entrance to the City Center. 
dizin sayılarında artış görülür. Bölgede en büyük dizin sayısı 6 dizin ile Aksu Çayı'nda görülür. Ancak Aksu Çayı konum olarak güneyde, şehir merkezinin dışında yer aldığından sel ve taşkın açısından şehir merkezine pek etkisi yoktur (Harita 5).

Strahler yönteminde, beslendiği herhangi bir yan kol olmayan az da olsa bir akış gösteren kollar 1. dizin olarak tanımlanmıştır. $\mathrm{Bu}$ 1. dizinlerden ikisi birleşirse 2. dizin, 2. dizinlerden her ikisi birleştiğinde ise 3. dizinler oluşacak şekilde dizinlerin hesaplaması yapılmaktadır (Strahler, 1957; Özdemir, 2011). İlk dizini besleyen yoktur ve her alt dizin, bir üst dizini besler. Dizin değeri arttıkça dizin segmentinde azalma gerçekleşir. Bu durum, akarsu dizinlerindeki hiyerarşik gelişiminin su toplanması ve büyük hacimli su kütlelerinin oluşma potansiyelinin göstergesidir. Akarsu dizin sıralamasında, göreceli olarak büyük su kütlesi oluşturma potansiyeline sahip olan alt havzaların taşkın duyarlılıkları daha yüksektir (Turoğlu ve Aykut, 2019). Şehir merkezini etkileyen akarsuların Strahler yöntemine göre sahip oldukları dizin sayıları ve bu dizinlerin toplam uzunlukları Tablo 1'de verilmiştir.

Tablo 1'e bakıldığında, dizin sayısı itibariyle toplam 1 dizin barındıran İğdeliöz Derenin 2978 m ile en kısa akarsu uzunluğuna sahip olduğu görülmektedir. Bunu 2 dizin barındıran Boğazdere ve Ağcalıdere takip etmektedir Bu nedenle bu 3 derenin büyük hacimli su kütleleri üretme potansiyelleri düşüktür. Bunun yanında Cancığın Dere 3 dizine sahipken Kerhan Çayı ve Karaçay 4 dizine sahiptir. Akdere ve Erkenez Çayı ise toplam 5 dizin sayıları ile bölgedeki en büyük su kütlesi oluşturma potansiyeli barındıran akarsular olduğu görülmektedir. Akarsular içerisinde en yüksek akarsu uzunluğu 407056 m ile Erkenez Çayı'nda görülür. Daha sonra bunu 142 698 m ile Akdere ve 97799 m ile Karaçay izlemektedir. Kahramanmaraş şehir merkezini etkileyen akarsuların havza alanları ve havza çevre uzunlukları (HÇU) Tablo 2'de verilmiştir.

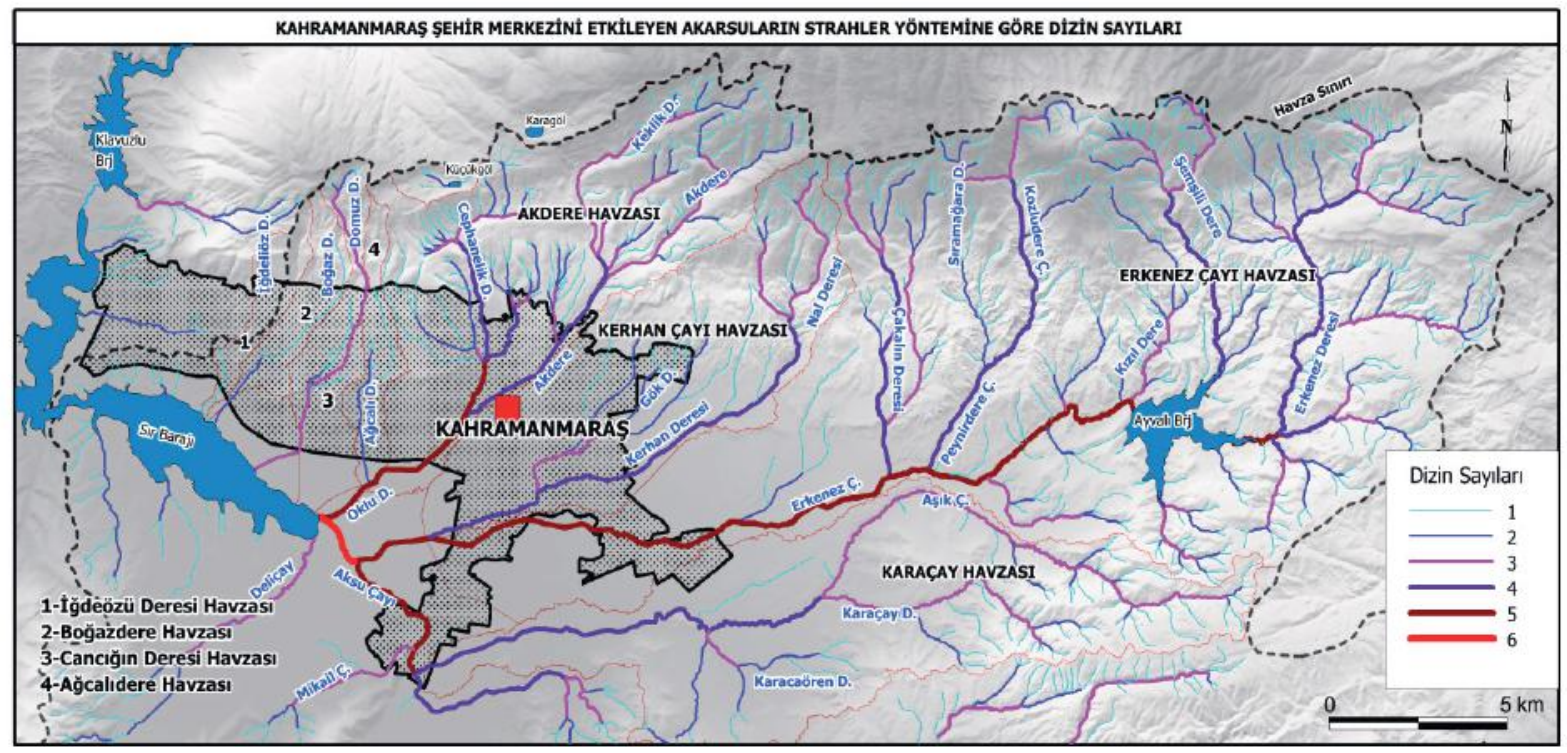

Harita 5: Şehir Merkezi Çevresindeki Akarsuların Strahler Yöntemine Göre Dizin Sayıları.

Map 5: Index Numbers of Streams Around the City Center According to Strahler Method.

Tablo 1: Kahramanmaraş Şehir Merkezini Etkileyen Akarsuların Strahler Yöntemine Göre Dizin Uzunlukları Table 1: Directory Lengths of Streams Affecting Kahramanmaraş City Center According to Strahler Method

\begin{tabular}{lcccccc}
\hline & 1.Dizin & 2.Dizin & 3.Dizin & 4.Dizin & 5.Dizin & Toplam (m) \\
\hline İğdeliöz D. & 2978 & - & - & - & - & 2978 \\
Boğazdere & 5013 & 2232 & - & - & - & 7245 \\
Cancığın D. & 5190 & 1746 & 9756 & - & - & 16692 \\
Ağcalı Dere & 4485 & 3832 & - & - & - & 8317 \\
Akdere & 68412 & 32309 & 23331 & 11685 & 6961 & 142698 \\
Kerhan Çayı & 31406 & 13077 & 10620 & 16857 & - & 71960 \\
Erkenez Çayı & 208767 & 87705 & 44196 & 38091 & 28297 & 407056 \\
Karaçay & 42322 & 17145 & 24922 & 13410 & - & 97799 \\
\hline
\end{tabular}


Tablo 2: Şehir Merkezi ve Yakın Çevresindeki Akarsuların Havza Alanı ve Havza Çevre Uzunlukları.

Table 2: Basin Area and Basin Perimeter Lenghts in City Center and Its Immediate Surroundings.

\begin{tabular}{lcccccccc}
\hline & İ̆geliöz Dere & Boğazdere & Cancığın Dere & Ağcalı Dere & Akdere & Kerhan Çayı & Erkenez Çayı & Karaçay \\
\hline Alan $\left(\mathrm{km}^{2}\right)$ & 5,08 & 6,44 & 11,5 & 6,20 & 65,07 & 51,69 & 228,6 & 78,4 \\
HÇU $(\mathrm{km})$ & 22,08 & 26,08 & 30,25 & 24,25 & 59,67 & 51,88 & 110,3 & 88,28 \\
\hline
\end{tabular}

Tablo 2'ye bakıldığında en geniş havza alanına sahip akarsuyun 228,6 km² ile Erkenez Çayı olduğu görülmektedir. Bunu 78,4 km² ile Karaçay ve 57,07 $\mathrm{km}^{2}$ ile Akdere takip etmektedir. En küçük havza alanı $5,08 \mathrm{~km}^{2}$ ile İğdeliöz Deresine ait olduğu görülmektedir. Diğer yandan Ağcalı Dere $6,20 \mathrm{~km}^{2}$, Boğazdere $6,44 \mathrm{~km}^{2}$ ve Cancığın Dere ise $11,5 \mathrm{~km}^{2}$ 'lik havza alanları küçük olan diğer derelerdir.

Kahramanmaraş şehir merkezi çevresinde şehir merkezini etkileyen akarsuların çizgisel ve alansal morfometrik özellikleri hesaplanmıştır. Çizgisel morfometrik özelliklerden Çatallanma oran1 $(R b)$, (Strahler 1964; Schumm, 1956), Uzunluk oranı $(R L)$, (Horton, 1945; Strahler, 1964) ve Tekstür oranlar1 (T), (Horton, 1945)'e göre hesaplanmıştır. Alansal morfometrik özelliklerden ise Drenaj yoğunluğu $(D d)$, (Horton, 1945), Akarsu sıklığı $(F S)$, (Horton, 1945), Havza şekli (Rf), (Horton, 1945) ve Uzunluk oranları $(R e)$, (Schumm, 1956)'a göre hesaplanmıştır. Çizgisel ve alansal morfometrik parametre analizleri yapılmış ve bu morfometrik analizler, şehir merkezindeki sel ve taşkın olayları üzerindeki akarsuların havza özelliklerinin de etkisini ortaya koymak açısından değerlendirilmiştir. $\mathrm{Bu}$ nedenle çalışmada morfometrik analizlerin hesaplanması konularının detaylarına değinilmemiştir.

Kahramanmaraş şehir merkezini sel ve taşkın açısından etkileyen akarsuların tümü şehrin güneyindeki Maraş Ovası'nda akış gösteren ve bölgenin ana akarsuyunu oluşturan Aksu Çayı'na bağlanır ve oradan Ceyhan Nehri üzerinde kurulmuş olan Sır Barajı'na dökülürler. Akarsuların morfometrik analizlerinin, sel ve taşkın duyarlılığı açısından değerlendirilme sonuçları Tablo 3'de gösterilmiştir.

Kahramanmaraş şehir merkezini etkileyen akarsuların sel ve taşkın duyarlılık değerlerine bakıldığında 13,8 ile Akdere ve 12,0 ile Erkenez Çayının “yüksek risk” sınıfında yer aldıkları görülmektedir (Tablo 3, Harita 6).

1972 yılında bugün şehir merkezine bağlı Dereli köyünde ve 2018 yıllarında şehir merkezinde yaşanan ve can kaybına neden olan sel afetlerinin her ikisi de Akdere havzası sınırları içerisinde meydana gelmiştir. Sel ve taşkın duyarlılığı en "yüksek” "ikinci akarsu havzası ise 12,0 ile Erkenez Çayı havzasıdır. Diğer yandan Karaçay, Kerhan Çayı, Cancığın Deresi havzaları "orta düzey” sel ve taşkın duyarlılığı gösterirken diğer yandan İğdeliöz Dere, Boğazdere, Ağcalıdere havzaları ise “düşük” düzeyde duyarlılık gösteren havzalar olduğu görülmektedir (Harita 6).

\subsection{Klimatolojik Faktörler}

Kahramanmaraş şehir merkezinde Akdeniz iklim özelikleri görülür. Yıllık ortalama sıcaklık 17,1 civarındadır. Yıllık ortalama toplam yağışı (1959-2018) 705,2 mm olup yağışların

Tablo 3: Kahramanmaraş Şehir Merkezi ve Yakın Çevresindeki Akarsuların Morfometrik Özellikleri.

Table 3: Morphometric Properties of Streams in Kahramanmaraş City Center and Its Immediate Surroundings.

\begin{tabular}{|c|c|c|c|c|c|c|c|c|c|}
\hline & \multicolumn{3}{|c|}{ Çizgisel Morfometrik Özellikleri } & \multicolumn{4}{|c|}{ Alansal Morfometrik Özellikler } & \multirow{3}{*}{$\frac{\varepsilon}{\frac{E}{0}}$} & \multirow{3}{*}{ 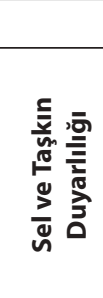 } \\
\hline & 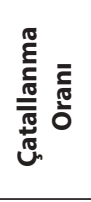 & 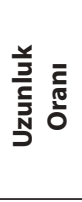 & 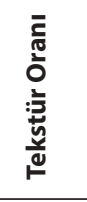 & • & 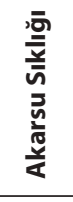 & $\begin{array}{l}\text { 言 } \\
\text { 心 } \\
\mathbb{N} \\
\text { N } \\
\text { İ }\end{array}$ & 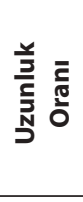 & & \\
\hline Akarsu Adı & $(R b)$ & $(R L)$ & $(T)$ & $(D d)$ & (Fs) & (Rf) & $(R e)$ & & \\
\hline İğdeliöz Deresi & 1,00 & - & 0,05 & 0,59 & 0,20 & 0,10 & 0,35 & 2,3 & Düşük \\
\hline Boğazdere & 1,00 & 2,24 & 0,08 & 1,12 & 0,47 & 0,10 & 0,35 & 5,4 & Düşük \\
\hline Cancığın Deresi & 1,65 & 1,57 & 0,26 & 1,45 & 1,30 & 0,12 & 0,39 & 6,7 & Orta \\
\hline Ağcalıdere & 1,30 & 1,17 & 0,16 & 1,34 & 1,13 & 0,10 & 0,36 & 5,6 & Düşük \\
\hline Akdere & 3,18 & 1,78 & 2,08 & 2,19 & 3,83 & 0,23 & 0,54 & 13,8 & Yüksek \\
\hline Kerhan Çayı & 2,86 & 1,51 & 0,61 & 1,54 & 1,23 & 0,22 & 0,53 & 8,5 & Orta \\
\hline Erkenez Çayı & 2,00 & 1,71 & 2,95 & 1,77 & 2,80 & 0,21 & 0,51 & 12,0 & Yüksek \\
\hline Karaçay & 3,20 & 1,72 & 0,67 & 1,25 & 1,47 & 0,14 & 0,42 & 8,9 & Orta \\
\hline
\end{tabular}




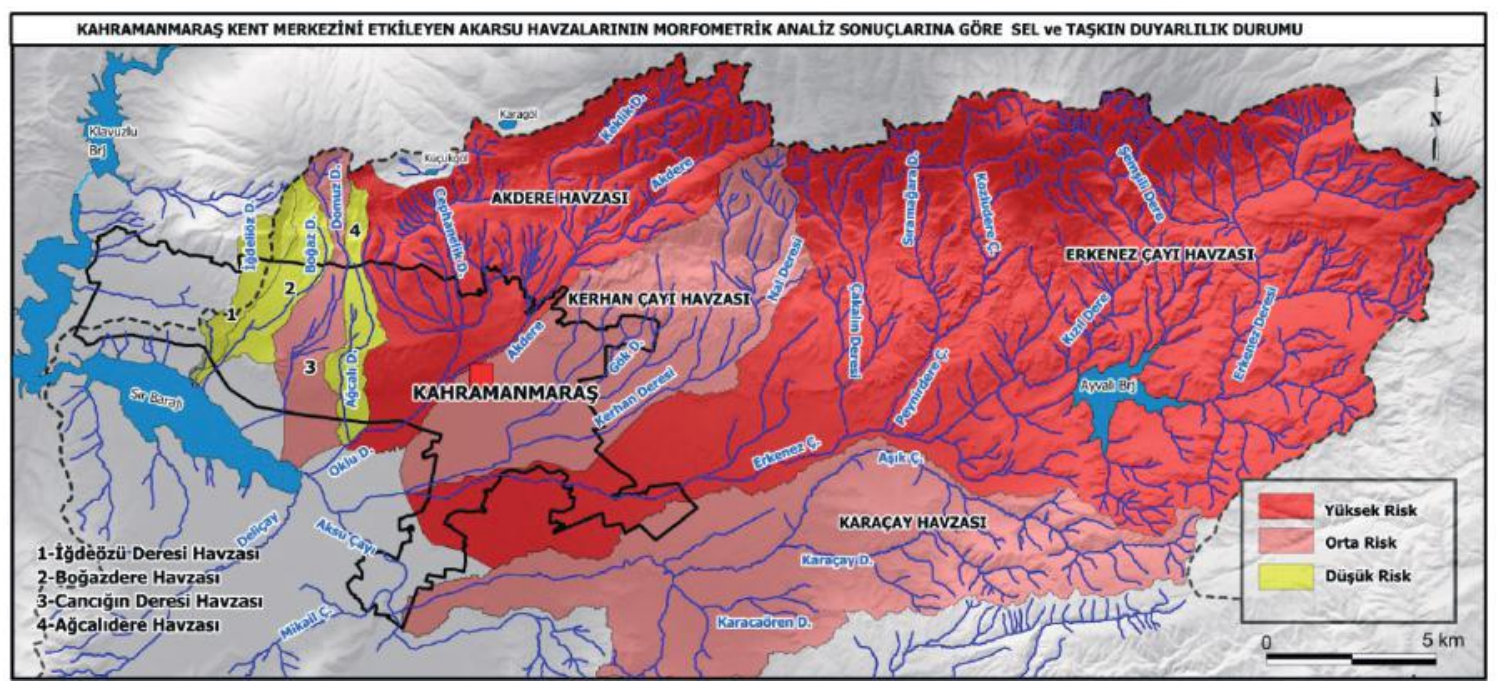

Harita 6: Akarsu Havzalarının Morfometrik Analiz Sonuçlarına Göre Sel ve Taşkın Duyarlılık Durumları. Map 6: Flood and Flashflood Sensitivity Results of Drainage Basins According to Morphometric Analysis.

çoğu kış aylarında düşmektedir. Thornthwaite iklim sınıflamasına göre C2 B'3 $^{\prime}$ s2 b'’3 $^{\prime}$ sinıfına giren şehirde Yarl Nemli, Orta sicaklikta (mezotermal), Su noksanı yaz mevsiminde ve çok kuvvetli olan, Okyanus iklimine yakın iklim özellikleri görülür.

Bir bölgede sel ve taşkın olaylarının incelenmesinde ve geleceğe yönelik öngörülerde bulunabilmek için bölgenin iklim elemanlarından özellikle sıcaklık ve yağıştaki değişim eğilimleri büyük önem arz etmektedir. Şehir merkezine ait 1959-2017 aras1 dönemdeki yıllık ortalama ve yıllık maksimum sıcaklıklar, 59 yıllık bir zaman dilimi için incelenmiş ve bu dönem 1959-1988 ve 1988-2017 arası dönemler olarak karşılaştırılmıştır.

Meteoroloji verilerine göre şehrin 1959-1988 yılları arası dönemde yıllık ortalama sıcaklığı $16,1^{\circ} \mathrm{C}$ iken, 1988 -2017 yılları arası dönemde toplam $1.0^{\circ} \mathrm{C}$ artış göstererek $17,1^{\circ} \mathrm{C}$ 'ye yükseldiğ $i$ görülmektedir. Diğer yandan yıllık maksimum sıcaklıkların ise
1959-1988 yılları arası dönemde $40,6^{\circ} \mathrm{C}$ iken $1988-2017$ yıllar arası dönemde $0,8^{\circ} \mathrm{C}$ artış göstererek $41,4^{\circ} \mathrm{C}$ 'ye yükseldiği görülmüştür (Grafik 1). Her iki türdeki sıcak değerlerinin de artış eğiliminde olduğu görülmektedir. Sicaklık değerlerindeki bu artışın, özellikle şehir merkezinin kuzeyindeki yüksek dağlık alanlarda meydana gelen kar erimeleri üzerindeki etkisi bakımından üzerinde durulması gereken önemli bir husustur.

Sel ve taşkın olaylarındaki yüzeysel akışa geçen veya biriken suyun esas kaynağını oluşturması bakımından bir yerin yağı̧̧ özellikleri oldukça önemlidir. Yağışın yıllık toplam miktarının yanında yağışın şiddeti, frekansı ve yıl içerisindeki dağılışı da çok önemlidir. Şehir merkezine ait yağış özellikleri "Nemli Dönem" (Ekim-Mart) ve "Kurak Dönem” (Nisan-Eylül) olarak incelenmiştir (Grafik 2). Dönemsel karşılaştırmanın yapılması ile iklim tipindeki değişimler hakkında çıkarımların yapılması amaçlanmıştır (Turoğlu, 2014).

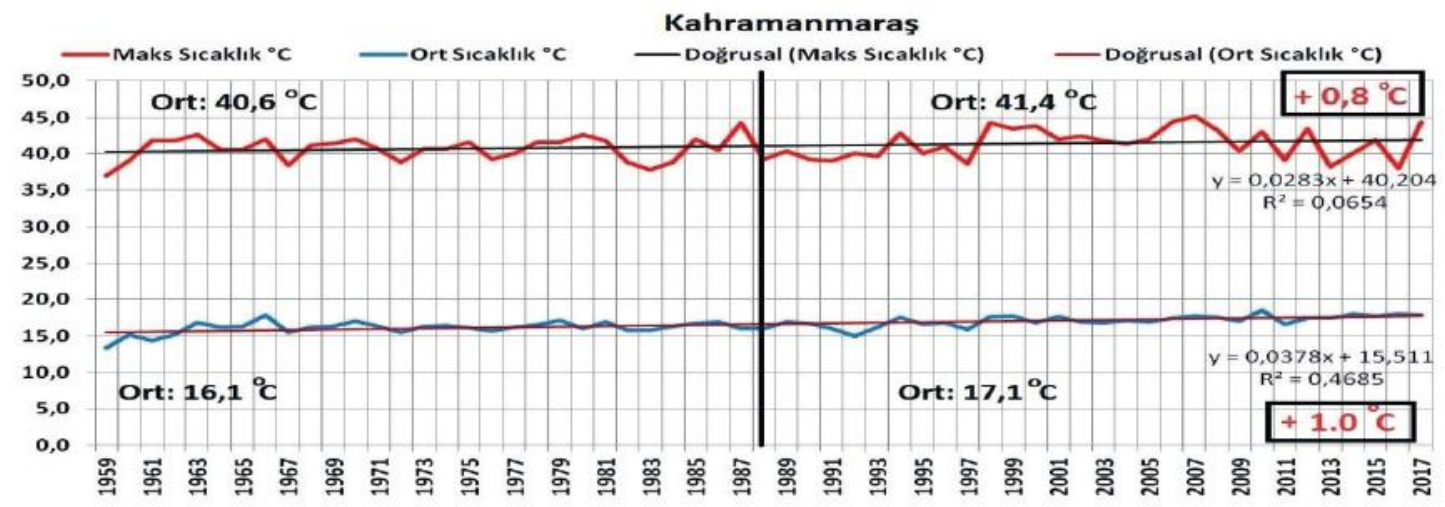

Grafik 1: Kahramanmaraş Şehir Merkezinin Yıllık Ortalama ve Maksimum Sıcaklık Eğilimleri. Graphic 1: Annual Average and Maximum Temperature Tendencies of Kahramanmaraş City Center. 




Grafik 2: Kahramanmaraş Şehir Merkezinin 1959-2018 Yılları Arası Yıllık Toplam Yağışın Dönemsel Eğilimleri. Graphic 2: Kahramanmaraş City Center's Periodical Tendencies of Annual Total Rainfall Between 1959-2018.

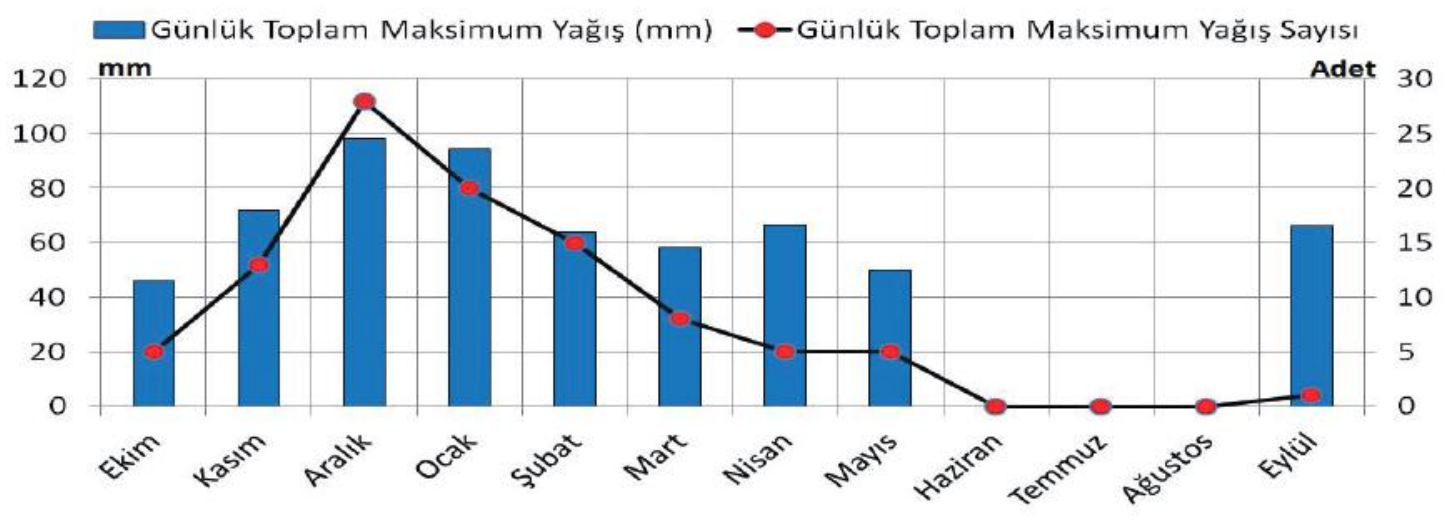

Grafik 3: Şehir Merkezine Düşen En Yüksek Günlük Maksimum Yağışların Aylara Göre Dağılışı. Graphic 3: The Monthly Distribution of The Highest Daily Maximum Precipitation in The City Center.

Şehir merkezine düşen yıllık toplam yağışlarda Nemli Dönem (Ekim-Mart) yağışlarının giderek azalma eğilimde olduğu, Kurak Dönem (Nisan-Eylül) yağışlarının ise bir artış eğilimi içinde olduğu görülmektedir (Grafik 2). Yağışların dönemsel eğilimine bakıldığında, şehir merkezindeki iklim tipinin bir değişim içerisinde olduğunu söylemek mümkündür. 1972, 2015 ve 2018 yillarında şehir merkezinde meydana gelen ve kayıtlara geçen tüm önemli sel afetlerinin Kurak Dönem (Nisan-Eylül) içerisinde meydana geldiği görülmektedir.

Şehir merkezine 1959-2018 yılları arası dönemde düşen en yüksek 100 adet günlük maksimum yağış sayıları ve miktarlarının aylara göre dağ 1 lış1 Grafik 3 'te incelenmiştir.

Günlük maksimum yağı̧̧ sayılarının aylara göre dağılımlarına bakıldığında günlük maksimum yağışların en sık Aralık ayında düştüğü görülmüştür. Bunu Ocak ve Şubat aylarında düşen yağışlar izlemektedir. İncelenen günlük yağışlar içerisinde en yüksek günlük maksimum yağış miktarı ise 98,2 mm ile Aralık (1989) ve 94,2 mm ile Ocak (2015) ayında düşmüştür. Daha sonra bunu 72,0 mm ile Kasım (2004) ve $66,5 \mathrm{~mm}$ ile Nisan (1977) ayları izlemektedir (Grafik 3).

Şehrin afet kayıtlarında can kayıpları yaşanan sel ve taşkın olaylarının meydana geldiği tarihlerde 1972 yılı için $31,3 \mathrm{~mm}$, 2018 y1lında ise $17,8 \mathrm{~mm}$ yağış düştüğü görülmektedir. Bu yağıŞ miktarlarından çok daha yüksek günlük yağışların olduğu Aralık ve Ocak aylarında herhangi bir sel afetlerinin yaşanmaması, bu afetlerin yaşanmasında yağışın toplamından ziyade şiddetinin etkisinin ne kadar önemli olduğunu ortaya koymaktadır.

1959-2018 aras1 dönemde incelenen en yüksek 100 adet günlük maksimum yağışın yıllara göre dağılımı ise Grafik 4 'te verilmiştir.

1959-2018 aras1 dönemde incelenen en yüksek 100 adet günlük maksimum yağış miktarları incelendiğinde bu yağış miktarlarını 98,2 $\mathrm{mm}$ ile $39,2 \mathrm{~mm}$ arasında değiştiği görülmektedir. $\mathrm{Bu}$ yağışların ortalaması $48,3 \mathrm{~mm}$ 'dir. $\mathrm{Bu}$ dönemde ölçülen en yüksek 100 adet maksimum yağışın 30 'unun 


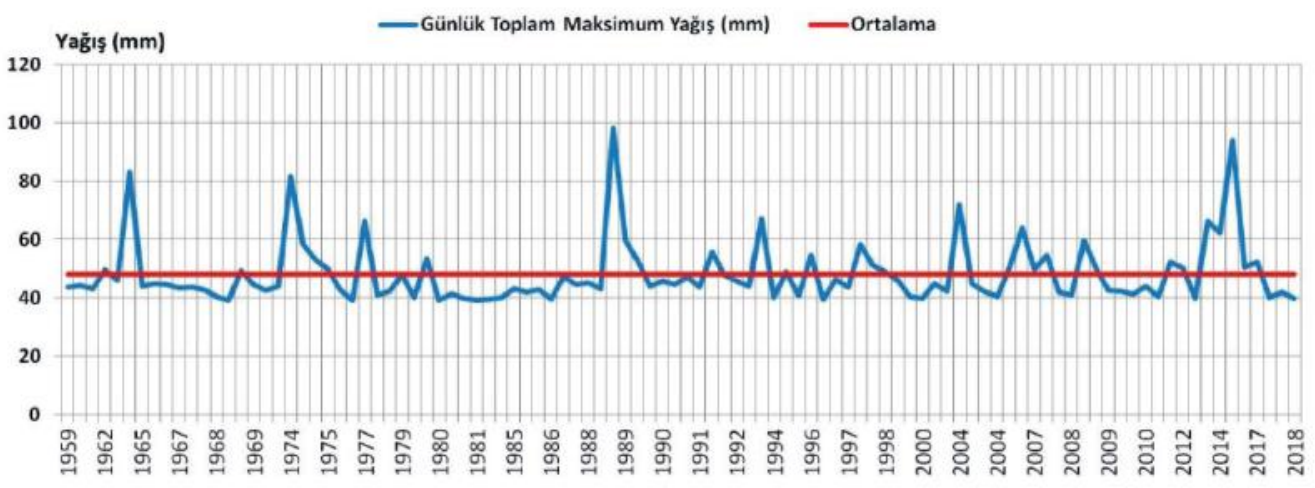

Grafik 4: 1959-2018 Arası Dönemde Düşen, En Yüksek 100 Adet Günlük Toplam Maksimum Yağışın Yıllara Göre Dağılımı. Graphic 4: The Annual Distribution of The Highest 100 Daily Total Maximum Rainfall in the Period Between 1959-2018.

2000 yılından sonraki dönemde düşmesi dikkat çekicidir (Grafik 4). $\mathrm{Bu}$ durum kentin yağış rejimindeki değişime işaret ettiği söylenebilir.

\subsection{Arazi Örtüsü// Kullanımı}

Şehrin kuzeyinde yer alan Ahır Dağı, Akdeniz-İran Turan Fitocoğrafya bölgelerinin geçiş kuşağında yer alır. Meşcere tiplerine göre yapılan sınıflandırmaya göre bölgede hâkim orman örtüsünü Kızılçam (Pinus brutia), Sedir (Cedrus libani), Karaçam (Pinus nigra), Ardıç (Juniperus) ve Meşe (Quercus) türleri oluşturmaktadır. Bölgenin ekolojik şartları ve beşeri faktörlerin de etkisiyle şekillenen Çalı (500-1200 m), Orman (800-1200 m) ve Alpin formasyonları (1800-2100 m) olmak üzere üç vejetasyon kuşağı görülür. Çalı formasyonu, Kızılçamların (Pinus brutia) uzun dönem boyunca tahrip edildikleri yerde ise hâkim formasyon Kermez meşesi (Qercus coccifera)'dir. Alpin kuşağı ise orman üst sınırı üzerinde ve bazı yerlerde ise tahribata bağlı olarak 18001900 metrelere kadar alçaldığı görülmektedir (Kısakürek, 1997; Doygun vd., 2014). Bölgede hâkim orman türünü Kızılçamlar
(Pinus brutia) oluşturmaktadır. Ancak bu kızılçam ormanları doğal ormanlar olmayıp ağaçlandırma ile oluşturulmuş yapay ormanlardır (Foto 6).

1950’lerde başlayan Kahramanmaraş Yeşil Kuşak Projesi, Ahır Dağı Ağaçlandırma Erozyon Kontrolü ve Mera Islah Projesi kapsamında bölgeye Kızılçam (Pinus brutia), Sedir (Cedrus libani), Korunga (Onobrychis), Aylantus (Ailanthus), Kapari (Capparis spinosa), Ceviz (Juglans), Badem ( Prunus dulcis), Akasya (Acacia), Mahlep (Cerasus mahaleb), Kuşburnu (Rosa canina) gibi türler dikilmiştir. Ancak ağaçlandırma çalışmaları birçok yerde başarılı sonuçlar vermiş olsa da Ahır Dağı yamaçlarında bazı bölgelerde erozyon riski hâlen ciddi bir şekilde devam etmektedir.

Sel ve taşkın afetlerini sadece iklim özellikleri gibi doğal olaylarla açıklamak mümkün değildir. Bunun yanında drenaj sistemlerine yapılan müdahaleler, sanayileşme, yerleşim bölgeleri için yanlış yer seçimi, doğal ortamların tahrip edilmesi

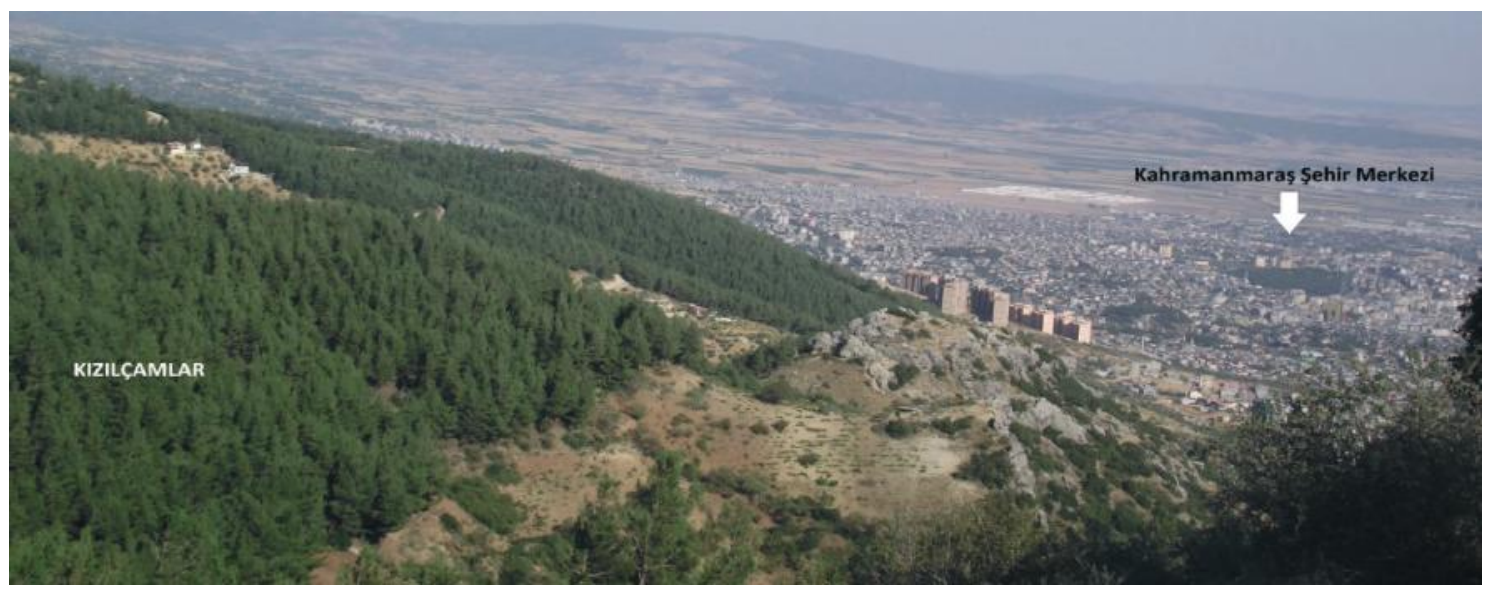

Foto 6: Ahır Dağı Yamaçlarında Yaygın Olarak Görülen Kızılçam Ormanları (Batıdan-Doğuya Bakış). Photo 6: Red Pine Forests Widely Seen On Mount Ahır Slopes (View From West to East). 
Tablo 4: K.Maraş Şehir Merkezi ve Yakın Çevresinin Arazi Örtüsü/Kullanımı Değişimleri (Doygun vd., 2014).

Table 4: Land Cover / Use Changes of Kahramanmaraş City Center and Its Immediate Surroundings (Doygun et al, 2014).

\begin{tabular}{|c|c|c|c|c|c|}
\hline \multirow{2}{*}{ Arazi Kullanımı/Arazi Örtüsü Sınıfları } & \multicolumn{2}{|c|}{1986} & \multicolumn{2}{|c|}{2013} & \multirow{2}{*}{ Değişim Oranı (\% } \\
\hline & (Ha) & (\%) & (Ha) & $(\%)$ & \\
\hline Kentsel Yapılar & 958,2 & 0,98 & 5324,2 & 5,45 & $+456,1$ \\
\hline Ekilebilir Alanlar & 27966 & 28,62 & 15983,4 & 16,36 & $-42,8$ \\
\hline Sürekli Ürünler & 20503,4 & 20,99 & 25413,7 & 26,01 & $+23,9$ \\
\hline İ̆ne Yapraklı Ormanlar & 4927,3 & 5,04 & 7336,4 & 7,51 & $+49,0$ \\
\hline Geniş Yapraklı Ormanlar & 12343,2 & 12,63 & 4651,4 & 4,76 & $-62,3$ \\
\hline Dağ Stepleri & 11380,4 & 11,65 & 19781,6 & 20,25 & $+73,8$ \\
\hline Seyrek Bitki Alanları & 14156,3 & 14,49 & 9885,7 & 10,12 & $-30,2$ \\
\hline Çıplak Kayalıklar & 4894,6 & 5,01 & 7998,3 & 7,27 & $+45,1$ \\
\hline Karasal Su Yüzeyi & 573,8 & 0,59 & 2228,8 & 2,28 & $+286,4$ \\
\hline
\end{tabular}

gibi konular da etkilidir. Tüm yaşanan bu olaylar sonucu arazi kullanımı ve arazi örtüsünde de değişimler meydana gelmektedir. Bu değişimleri yönlendiren en önemli faktörlerin başında halkın sosyo-ekonomik yaşamındaki değişim özellikleri gelmektedir (Turoğlu ve Özdemir, 2005).

Kahramanmaraş şehir merkezi nüfusu TÜIKK verilerine göre 1965 yılında 63.284 iken şehrin sanayileşmesine bağlı olarak 1990'lı yıllardan itibaren nüfusu hızlı bir artış sürecine girmiş ve 2018 y1lına gelindiğinde 641.317'ye yükseldiği görülmüştür. Şehir merkezinin yerleşim olarak büyük oranda genişlemesi ile şehir merkezi ve çevresinde arazi örtüsü/kullanımı önemli ölçüde değişime uğramıştır.

Şehir merkezi ve yakın çevresindeki "Sinıflandırma Sonrası Karşılaştırma Tekniği”" ile belirlenmiş olan 9 farklı arazi örtüsü / kullanım sınıfı ve bu sınıflardaki 1986-2013 yılları arası dönemdeki değişim oranları Tablo 4'de verilmiştir (Doygun vd., 2014).
Tablo 4'e bakıldığında 1986 'da \% 0,98 oranında olan kentsel yapılar, 2013 yılına gelindiğinde neredeyse 4,5 kat artış göstererek \% 5,45'e yükselmiştir. Şehir merkezinde, arazi örtüsü/kullanımının kentsel yapılardan sonra en fazla değişimi $\%$ 0,59'dan, \% 2,28'e yükselmiş olan karasal su yüzeylerinde gerçekleşmiştir. Bu değişimde 1990'lı yıllarda yapılan barajlar etkili olmuştur. Diğer yandan iğne yapraklı orman alanlarında ise \% 49 oranında bir artış görülmüştür ki bu artışta bölgede yapılan kızılçam (Pinus brutia) ve sedir (Cedrus libani) türlerindeki ağaçlandırma çalışmalarının etkisi büyüktür. Buna karşın ekilebilir alanlarda yani tarım alanlarında $\% 42$, seyrek bitkili alanlarda $\% 30$ ve geniş yapraklı orman alanlarında ise $\% 62$ oranında azalma gerçekleşirken, dağ stepleri alanındaki \% 73 oranındaki artış meydana gelmiştir. (Doygun vd., 2014). $\mathrm{Bu}$ durum bölgede bitki örtüsü tahribatının olduğuna işaret etmektedir. Ahır Dağ1 yamaçlarında bitki örtüsünün tahrip edilmesinde kentleşme, orman yangınları ve küçükbaş hayvancılık gibi beşeri faaliyetlerin etkisi önemlidir (Foto 7).



Foto 7: Ahır Dağı Yamaçlarında Bitki Örtüsü Tahribatına Neden Olan Faaliyetlerinden Bir Görünüm. Photo 7: A View From The Effects of Human Activities On Mount Ahır Slopes. 
$\mathrm{Bu}$ dönem içerisinde önemli büyüme sürecine giren şehir merkezi, kuzeye doğru yönelmiş ve Ahır Dağı yamaçları boyunca gelişme göstermiştir. 1984 y1lında 650 metre civarında olan yerleşme üst sınırı, 2018 yılına gelindiğinde 850 metreye ulaş ve Ahır Dağı'nın güney yamacı boyunca şehir merkezi 200 metre yükselmiştir (Şekil 2).

Şehir merkezinin 1984 yılına ait yerleşme üst sınırına bakıldığında şehrin kuzeyinde yer alan yüksek kesimlerde geçirimliği yüksek Kuvaterner, birikinti konisi-yamaç molozlarının (Qym) bulunduğu görülmektedir. O dönem için kuzeyden gelen dereler, şehir merkezine ulaşmadan önce bu birimler üzerinde sızmanın etkisi ile yüzeysel akışta azalmaya neden olarak sel ve taşkın risklerini azaltan bir rol üstlendiği söylenebilir. 2018 yılına gelindiğinde ise şehir merkezi yerleşim üst sinırının 200 metre yükselmesi ile kuzeyde yer alan Ahır Dağ1 yamaçlarındaki yüksek kesimlerde geçirgenliğin yüksek (\% 35) olduğu Kuvaterner'e ait birikinti konisi ve yamaç molozu birimlerinin (Qym) bulunduğu alanlar şehir alanlarına dönüştürülmüştür. Bunun sonucu şehir merkezi, geçirgenliğin düşük (\% 15) olduğu kuzeydeki Eosen killi kireç taşı (Tmt) birimlerine dayanmıştır. Bu durumun sonucunda, yağış sularının infiltrasyona uğramadan doğrudan şehir merkezine drene olmasına ve bu derelerle gelen suların şehir merkezinde toplanması ve büyük hacimlere ulaşması, şehir merkezinde sel ve taşkın riskinin yükselmesine neden olmaktadır (Şekil 3).

Şehir merkezi ve çevresindeki ormanların dağıllısına bakıldığında, şehrin doğu ve güneydoğusuna gidildiğinde orman alanları ve yoğunluğu artış gösterir. Özellikle Aşık Çayı ve Karaçay'ın kaynağını aldığı bölgeler ile Ayvalı Barajı'nın doğusundaki alanlarda kapalılık düzeyi 3 olan gelişmiş ormanlar yer alır. Şehrin kuzey ve kuzeydoğusuna doğru gidildiğinde ise orman örtüsü yoğunluğunun gittikçe azaldığı görülmektedir. Bu bölgelerde kapalılık düzeyi 1 olan gevşek kapalı alanları oluşturan seyrek ve c1lız ormanlar bulunur (Harita 7).

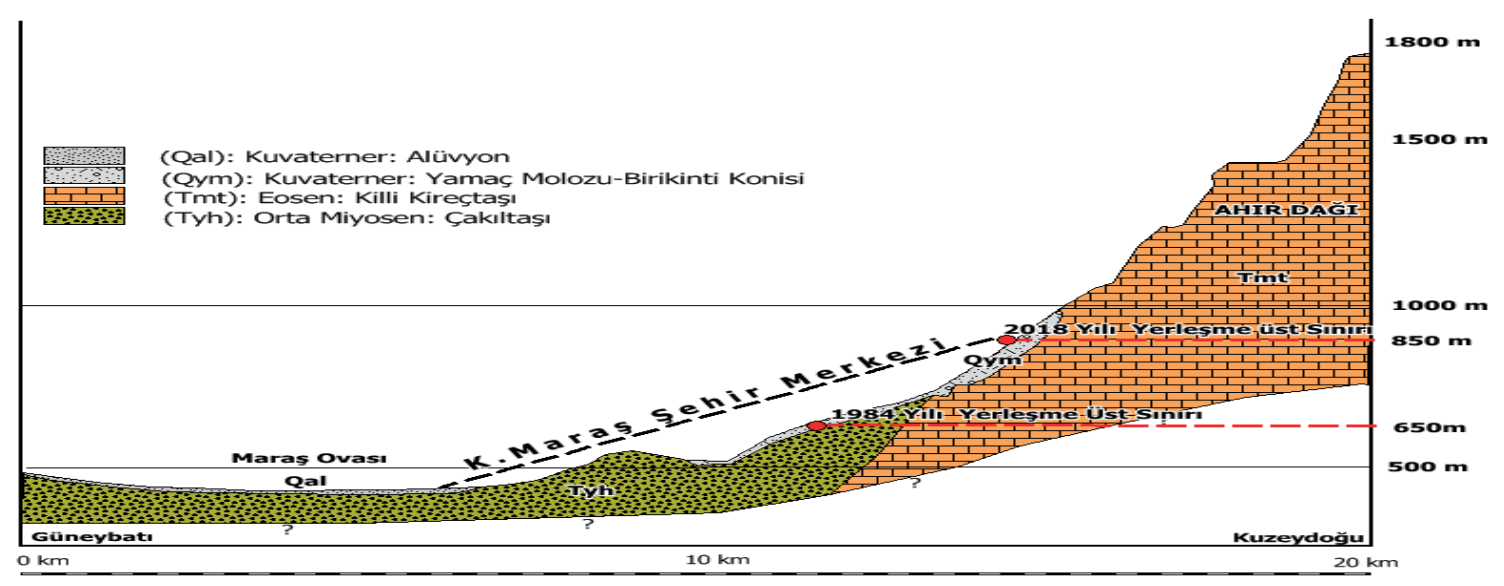

Şekil 3: Kahramanmaraş Şehir Merkezinin Yerleşme Üst Sınırının Değişimi (DSi, 2015'e göre düzenlenmiştir). Figure 3: Change on the Settlement Limit of Kahramanmaraş City Center (DSI is regulated according to 2015).

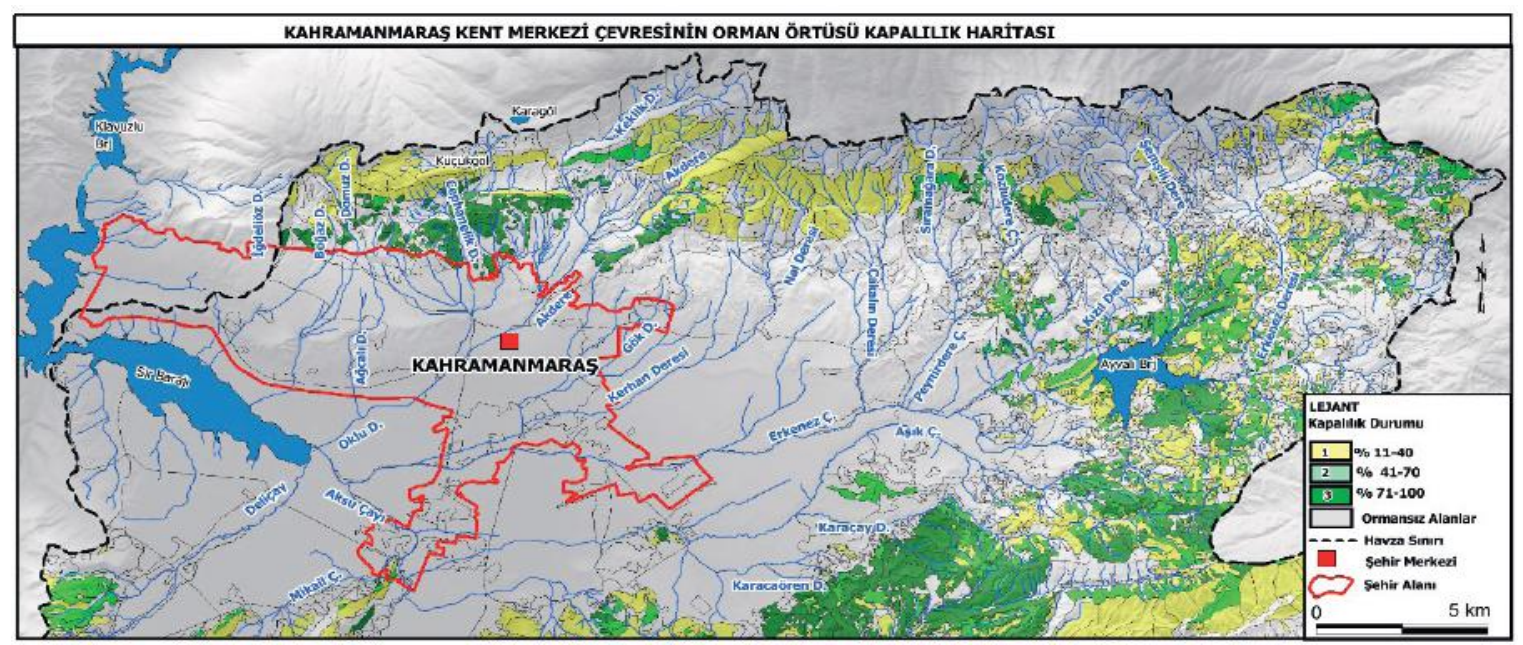

Harita 7: Kahramanmaraş Şehir Merkezi ve Yakın Çevresinin Orman Örtüsü Kapalılık Haritası. Map 7: Forest Cover Closure Map of Kahramanmaraş City Center and Its Vicinity. 
Akdere, Keklik Dere, Küçüknacar, Çakalın Deresi, Nal Deresi, Kozludere ve Şemşili Derelerin bulunduğu yerlerde hem eğim ve yükselti fazla hem de orman örtüsünden yoksun sahalar fazladır (Harita 7). Bu yüzden bu bölgelerde yüzeysel akışın azaltılması ve erozyon kontrolü için buralarda ağaçlandırma çalışmalarının yoğunlaştırılması ve yamaçlardan şehir merkezine inen derelerde tersip bentleri gibi önlemlerin alınması önem arz etmektedir.

\section{TARTIŞMA VE SONUÇ}

Kahramanmaraş şehir merkezinde iklim elemanları analizleri ve iklim elemanlarındaki eğilimler şehir merkezinde sel ve taşkın afetlerinin, sıklıklarının ve afet boyutlarının artacağına işaret etmektedir. 1959-2018 arası dönemde gerçekleşen en yüksek 100 adet günlük maksimum yağışın 30'unun 2000 yılından sonraki dönemde düşmüş olması bunu kanıtlar niteliktedir. Diğer yandan yıllık toplam yağışlarda Kurak Dönem (Nisan-Eylül) yağışlarının giderek artış içinde olduğu, Nemli Dönem (Ekim-Mart) yağışlarının ise bir azalma eğilimi içinde olduğu görülmektedir. Tüm bu gelişmeler, kentin yağış rejimindeki bir değişime işaret etmektedir.

Şehir merkezinde yaşanan sel ve taşkın afetlerinde artış yaşanmasında iklim elemanlarındaki eğilimlerin yanı sıra şehirdeki beşeri sistemlerde yapılan yanlış uygulamalar da etkili olmaktadır. Özellikle şehrin kuzey yönde gelişmesi ile kuzeyde bulunan yüksek, eğimli ve aynı zamanda geçirgenliği yüksek alanların betonlaştırılması ve buralarda yaşanan yapılaşma faaliyetleri ve orman yangınları sonucu yaşanan bitki örtüsünün tahrip edilmesi, yağışlar sonucu şehir merkezine doğru yüzeysel akışa geçen suyun hızını ve miktarının artmasına neden olmaktadır. Bu yüzden şehrin kuzeyindeki yeşil alanlar korunmalı ve şehrin kuzey yönde gelişimi engellenmelidir. Buna karşın gerek tarım alanlarının korunması gerekse sel, taşkın ve deprem tehlikelerinden korunmak adına şehrin yeni gelişim yönünün Önsen, Fatmalı ve Kale mahallelerinin bulunduğu güneybatı taraflarına yönelmesi gerekir.

Akarsu havzalarının morfometrik analiz sonuçlarına göre sel ve taşkın duyarlılıklarına bakıldığında "en yüksek risk" Akdere ve Erkenez Çayı havzalarında olduğu görülmüştür. 1972 ve 2018 yıllarında şehir merkezinde can kaybına neden olan sel afetlerinin her ikisi de Akdere havzası sınırları içerisinde yaşandığı dikkate alınırsa, Akdere havzasında alınacak önlemler, bu anlamda mühimdir. Diğer yandan Karaçay, Kerhan Çayı ve Cancığın Dere havzalarında "orta seviyede risk" görülürken İğdeliöz, Ağcalıdere ve Boğazdere havzalarında ise "düşük seviyede risk" olduğu görülmüştür.
Sel ve taşkın riskinin en yüksek olduğu Akdere havzası içerisinde yer alan, Akdere, Keklikdere, Kandil Dere, Cephanelik Dere, Kadiroğlu Dereleri şehir merkezinde, Gayberli mahallesinde birleşirler. Burada toplanan sular, geçmişte kapalı kanala alınmış olan Oklu Dere tarafindan Aksu Çayı'na drene edilir. Yağışın yüksek olduğu bazı zamanlarda burada biriken suların derene edilmesinde, kanalın kapasitesi yetersiz kalmaktadır. Bu yüzden kentleşmeye bağlı olarak betonlaşmanın da etkisi göz önüne alınarak veyüzeysel akışa geçen sumiktarı yeniden değerlendirilerek Oklu Dere'nin kanal genişliği yeniden düzenlenmelidir. Sonuç olarak Kahramanmaraş şehri imar planı revizyonunda, afet yönetim planlamasında ve dere sslah projelerinde bu çalışma sonuçlarının dikkate alınması önerilmektedir.

Hakem Değerlendirmesi: Dış bağımsız.

Çıkar Çatışması: Yazarlar çıkar çatışması bildirmemiştir.

Finansal Destek: Yazarlar bu çalışma için finansal destek almadığını beyan etmiştir.

Peer-review: Externally peer-reviewed.

Conflict of Interest: The authors have no conflict of interest to declare.

Grand Support: The authors declared that this study has received no financial support.

\section{KAYNAKÇA/REFERENCES}

Atalay, İ. (2013). Uygulamalı klimatoloji (2. Bask1). İzmir: Meta Basımevi. Türkiye.

Bayazit, M. (1995). Hidroloji. İstanbul: İstanbul Teknik Üniversitesi Yay. Türkiye.

Doygun, H., Kısakürek, Ş., Erdoğan, N., Hatipoğlu, İ, H. (2014). Kahramanmaraş-Ahır Dağl bitki örtüsü değişiminin uzaktan algılama ile incelenmesi. II. Akdeniz Orman ve Çevre Sempozyumu Bildiriler Kitab1, 721-728. Süleyman Demirel Üniv, Isparta.

DSİ (2015). Ceyhan Havzası hidrojeoloji raporu. Orman ve Su İşleri Bakanlığı. Kahramanmaraş: DSİ 20. Bölge Müdürlüğü Yayınları, 410-501.

Ersoy, Ş. (2017). 2016 yllı doğa kaynaklı afetler yılllğg. Ankara: JMO Yayınları. Türkiye.

Horton, R. E. (1945). Erosional development of streams and their drainage basins: 1 approach to quantitative morphology. Bulletin of the Geological Society of America, 56: 275-370.

Kısakürek, Ş. (1997). K.Maraş Ahır Dağı bünyesinde ekolojik unsurlarla dengeli alan kullanım ilkelerinin belirlenmesi, (Yüksek Lisans Tezi) Çukurova Üniversitesi, Fen Bilimleri Enstitüsü. Adana.

Özdemir, H. (2011). Havza morfometrisi ve taşkınlar. Fiziki Coğrafya Araştırmaları Sistematik ve Bölgesel kitabı içerisinde 5.Bölüm (s.507-526). İstanbul: Türk Coğrafya Kurumu Yayınları. Türkiye.

Strahler, A. N. (1957). Quantitative analysis of watershed geomorphology. Trans Am Geophysical Union, 38, 913-920.

Strahler, A.N.(1964). Quantitative geomorphology of drainage basins and channel Networks.In: Chow VT (Ed) Handbook of applied hydrology. Newyork, pp 4-40-4-74. 
Sunkar, M. \& Denizdurduran, M. (2015). Kahramanmaraş'ta yaşanan sel ve taşkın olaylarının sebepleri ve sonuçları. IV. Ulusal Jeomorfoloji Sempozyumu Bildiriler Kitab1 içinde (s.652-661). Samsun.

Schumm, S. A. (1956). Evolution of drainage systems and slopes in badlands at Perth Amboy, New Jersey. Geological Society of America Bulletin, 67: 597-646.

Şen, Z. (2003). Su bilimi ve yöntemleri. İstanbul: Su Vakfı Yayınları. Türkiye.

Turoğlu, H. (1997).İyi dere havzasının, hidrografik özelliklerine sayısal bir yaklaşım. Türk Coğrafya Dergisi, (32), 355-364.

Turoğlu, H. (2010a) Şehirsel gelişmenin İstanbul selleri üzerindeki etkisi. İstanbul'un Afetlerden Zarar Görebilirliği Sempozyum Bildiriler Kitabı içinde.( s.55-59). İstanbul.

Turoğlu, H. (2010b). Yapılaşmanın doğal akım yönü ve akım birikimi üzerindeki etkileri. TÜCAUM, 6. Ulusal Coğrafya Sempozyumu, Bildiriler Kitabı içinde (s.29-36). Ankara Üniversitesi, Ankara.
Turoğlu, H. (2014). İklim değişikliği bağlamında İstanbul'da su yönetimi problemleri. TÜCAUM, 8. Coğrafya Sempozyumu Bildiriler Kitabı içinde (s.97-107) Ankara Üniversitesi. Ankara.

Turoğlu, H. (2019). Şehir seli ve taşkını araştırmalarında sayısal yüzey modellemesi (SYM) ve insansız hava aracı (İHA) verisi kullanımı. E. Akköprü, M. F. Döker (Edt) Coğrafya Araştırmalarında Coğrafi Bilgi Sistemleri Uygulamaları kitabı içinde, 1. Bölüm, sayfa: 01-28. Pegem Akademi Yayınevi.

Turoğlu, H. \& Aykut, T. (2019). Ergene nehri için hidromorfometrik analizlerle taşkın duyarlılık değerlendirilmesi. Jeomorfolojik Araştırmalar Dergisi, 2: 1-15.

Turoğlu, H. \& Özdemir, H. (2005). Bartın'da sel ve taşkınlar, sebepler, önleme ve zarar azaltma önlemleri. İstanbul: Çantay Kitabevi. Türkiye. 
